Article

\title{
Numerical Modeling of Meteotsunami-Tide Interaction in the Eastern Yellow Sea
}

\author{
Ki-Young Heo ${ }^{1}$, Jae-Seon Yoon ${ }^{2}$, Jae-Seok Bae ${ }^{3}$ and Taemin Ha ${ }^{4, *}$ \\ 1 Marine Disaster Research Center, Korea Institute of Ocean Science \& Technology, Busan 49111, Korea \\ 2 Rural Research Institute, Korea Rural Community Corporation, Ansan 15634, Korea \\ 3 Emergency Management Office, Korea Hydro \& Nuclear Power Co., Ltd., Gyeongju 38120, Korea \\ 4 Department of Civil Engineering, Kangwon National University, Samcheok 25913, Korea \\ * Correspondence: tmha@kangwon.ac.kr; Tel.: +82-033-570-6514
}

Received: 24 May 2019; Accepted: 1 July 2019; Published: 2 July 2019

\begin{abstract}
Meteotsunamis originating from atmospheric pressure disturbances have frequently occurred in oceans worldwide and their destructive long waves have recently threatened local coastal communities. In particular, meteotsunamis occurring in the Yellow Sea caused unexpected casualties and property damage to local communities on the western coast of the Korean Peninsula in 2007 and 2008. These events attracted the attention of many engineers and scientists because abrupt extreme waves have struck several coasts and ports even under fine weather conditions. Furthermore, the Yellow Sea has the highest tide and most powerful tidal currents in the world, and consequently, meteotsunami events there could be more destructive and harmful to local coastal communities when such events occur during high tide or a critical phase with strong tidal currents. In this study, numerical experiments were conducted to identify the qualitative effect of the interaction between a meteotsunami and the tide on the generation and amplification mechanisms of meteotsunamis occurring in the Yellow Sea. In general, small-scale meteotsunamis, such as those that occur in the Yellow Sea, should be analyzed using a high-resolution modeling system because water motions can be affected by local terrain. To achieve this objective, high-resolution atmospheric modeling was conducted to reproduce the atmospheric pressure disturbances observed in the Yellow Sea; then, the generation and propagation of the meteotsunami over real topographies was simulated using a phase-resolving wave model. Both an atmospheric model (Weather Research and Forecasting Model (WRF)) and a shallow water equation model (COrnell Multigrid COupled Tsunami Model (COMCOT)) were employed to simulate the generation and transformation of the meteotsunami.
\end{abstract}

Keywords: meteotsunami; tide; atmospheric model; phase resolving wave model; nonlinear interaction

\section{Introduction}

The name "meteorological tsunami" (i.e., "meteotsunami") was suggested for the long waves associated with atmospheric disturbances by references [1-3]. There are some local names for this phenomenon (e.g., "Abiki", "Rissaga", "Marrubio", etc.) because long wave accidents induced by atmospheric pressure disturbances had already been reported before the term meteorological tsunami was proposed. The generation mechanism of meteotsunamis can be summarized as follows: water surface disturbances in the ocean from an atmospheric pressure jump are amplified by Proudman resonance $[4,5]$. Then, the wave height increases due to the shoaling effect, resulting in hazardous oscillations in the basin because of harbor resonance. Namely, atmospherically induced long waves continuously gain energy from the traveling atmospheric pressure jump, of which the traveling speed is equal to propagation speed of long waves [6]. 
On 31 March 2007, a meteorological tsunami generated in the middle of the Yellow Sea caused three casualties and local flooding along the western coast of the Korean Peninsula. Another meteorological tsunami was generated in the Yellow Sea on 4 May 2008 and caused nine casualties. These events attracted the attention of many engineers and scientists because abrupt extreme waves have attacked several coasts and ports even under fine weather conditions. Furthermore, the meteotsunami that occurred in 2008 was a small-scale event and caused extreme waves only at Jukdo Island, unlike the previous meteorological tsunami that occurred in 2007, which caused abnormally extreme waves along the western coast of the Korean Peninsula. There have been many studies conducted to identify the underlying processes of meteotsunamis and our understanding of them has substantially improved [7-11]. Nevertheless, many issues still remain unresolved. Although it is well known that Proudman resonance plays a dominant role in meteotsunami-related atmosphere-ocean energy transfer, detailed amplification processes of meteotsunamis influenced by the local bathymetry have not been sufficiently identified yet. Variable topographies can affect the transformation of sea waves, causing features such as depth-induced refraction and shoaling, and these should be considered in order to identify the amplification mechanism [12,13].

A meteotsunami may experience some interaction with various physical processes during its journey in the open ocean. In general, tide and tidal currents can be strong in the Yellow Sea and may have powerful effects on the generation and propagation processes of a meteotsunami. As a result, for some regions with very strong tides (e.g., the Yellow Sea and the East China Sea), the interaction between the tide and a meteotsunami may be strengthened significantly, which should be considered when predicting meteotsunami hazards in Korea (Figure 1) [13-15]. Since propagation of a meteotsunami is highly influenced by tidal elevations in a shallow water zone with dominant tidal signals, a significant effect of tide-meteotsunami interaction should be observed in the tidal and meteotsunami currents. Furthermore, it was demonstrated that water depth increments caused by tides should be considered during the run-up process because the near-shore bathymetry plays a significant role in the run-up computation [16-18]. Therefore, the interaction between tide and meteotsunami, which occurs during propagation over some regions with strong tides and tidal currents, should be properly evaluated beforehand and its impact on local communities and public property near the coast of the Korean Peninsula should be considered during numerical simulations.

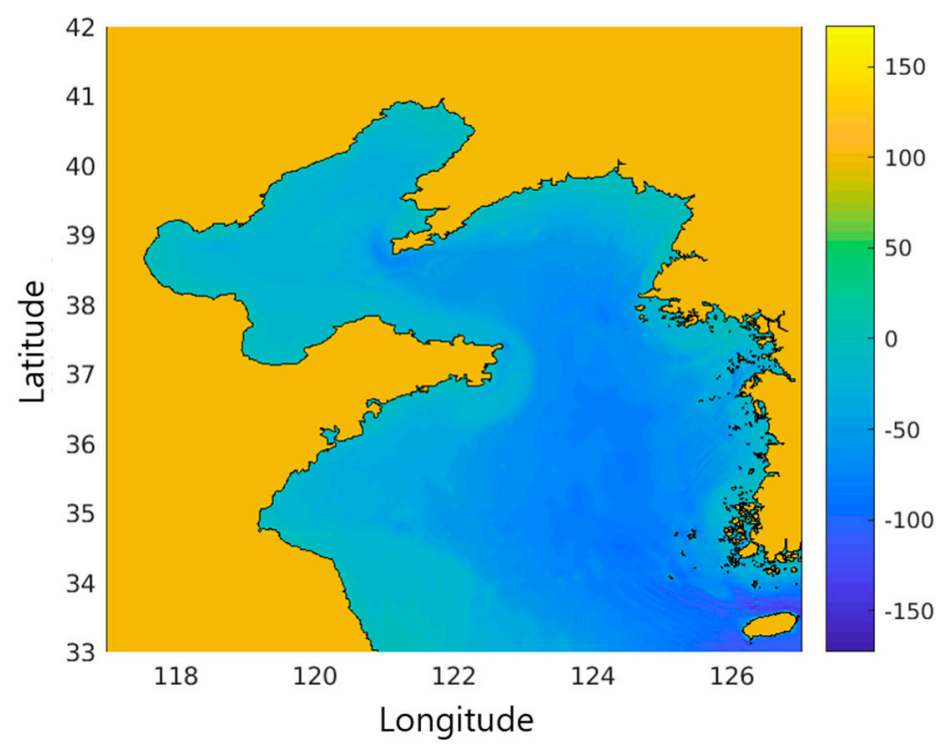

Figure 1. Bathymetry of the Yellow Sea and numerical domain.

In this study, a series of numerical experiments were conducted to identify the generation and amplification mechanisms of meteotsunamis occurring in the Yellow Sea, and numerical results with and without tide modeling were analyzed to examine the interaction between a meteotsunami and the 
tide. In general, small-scale meteotsunamis, such as the events that occurred in the Yellow Sea, should be analyzed using a high-resolution modeling system because water motions can be affected by local terrain. To achieve the objective, high-resolution atmospheric modeling was conducted to reproduce the atmospheric pressure disturbances observed in the Yellow Sea. Then, the generation and propagation of the meteotsunami over real topographies was simulated using a phase-resolving wave model. Both an atmospheric model (Weather Research and Forecasting Model (WRF)) and a well-known shallow water equation model (COrnell Multigrid COupled Tsunami Model (COMCOT)) were employed to simulate the generation and transformation of meteotsunamis. The historical meteotsunami events were analyzed first using the available observational data to identify generation and amplification processes of meteotsunamis in the Yellow Sea. Then, numerical modeling of the meteotsunamis was conducted with tide modeling and the whole process of transformation was analyzed to identify tidal effects on the processes of the past meteotsunamis in the Yellow Sea.

\section{Data and Model Description}

\subsection{Atmospheric Modeling Configuration}

In this study, we employed the Advanced Research core of WRF (ARW) [19] version 3.7.1 and its own data assimilation system known as WRFDA [20] to perform regional atmospheric reanalysis in a high-resolution grid system, including the sea level pressure necessary to force the meteotsunami hindcasts. The model utilized data assimilation to adjust initial conditions and to improve final reanalysis data. Configuration parameters and physical schemes of the model are summarized in Table 1. The atmospheric modeling domain encompassed the East Asian region, including the Korean Peninsula. The domains have a grid spacing of 20 and $4 \mathrm{~km}$ with 60 vertical levels and a model top of $50 \mathrm{hPa}$ [13].

Table 1. Overview of WRF model configuration parameters and physical schemes [21].

\begin{tabular}{ccc}
\hline Description & Option & Configuration \\
\hline \multirow{4}{*}{ Physics } & Microphysics & WSM5 [22] \\
& Longwave radiation & RRTMG [23] \\
& Shortwave radiation & RRTMG [23] \\
& Planetary boundary layer & YSU PBL [24] \\
& Surface layer & Monin-Obukhov \\
& Land surface model & Noah LSM \\
Grid & Cumulus & Kain-Fritsch [25] \\
WRFDA & Horizontal grid spacing & 20 km, $4 \mathrm{~km}$ \\
& Surface assimilation option & 31 levels with top at 50 $\mathrm{hPa}$ \\
\hline
\end{tabular}

The real-time analysis data were obtained from the global final analysis (FNL) data run by ECMWF ERA-Interim with $0.75^{\circ}$ resolution. The data provided atmospheric forcing and initial conditions of the model for soil moisture and temperature. The ERA-Interim is based on a four-dimensional variational analysis (4DVAR) with a $12 \mathrm{~h}$ analysis window. Because numerical errors of forecasting data dramatically increase with time after one day past, even with frequent data assimilation, the model was reinitialized daily with the ERA-Interim providing initial and lateral boundary conditions, and available observational data were assimilated every $6 \mathrm{~h}$, including the initial hour. The results from the first $6 \mathrm{~h}$ of each run were used as model spin-up and were removed from consideration. The remaining one-day periods were pieced together to form a continuous time series [21].

\subsection{Wave Modeling Configuration}

Shallow water equation models have been widely used to study water wave motion and are generally preferred by scientists and engineers to simulate tsunami propagation and run-up because they offer efficient computation capability with relatively reasonable accuracy. There have been many successful case studies analyzing tsunami motion and effects on coastal areas using these shallow water 
equation models [15]. Among others, the new version of COMCOT, a well-known tsunami model based on the shallow water theory with improved dispersion effects [26], has been released recently and applied to various tsunami cases [15]. Recently, $[7,11]$ employed the nonlinear shallow water equation model to simulate inundation along the western coast of the Korean Peninsula from the meteotsunami that occurred in 2007. Like their study, the nonlinear shallow water equations we used included the nonlinear effects caused by sea level pressure changes, and we slightly modified the COMCOT model to consider dynamically time-varying sea level pressure changes during computation [13]. The following modified nonlinear shallow water equations (Equations (1)-(3)) were employed in the new COMCOT model to simulate propagation of a meteotsunami in the Yellow Sea:

$$
\begin{gathered}
\frac{\partial \varsigma}{\partial t}+\frac{\partial P}{\partial x}+\frac{\partial P}{\partial y}=0 \\
\frac{\partial P}{\partial t}+\frac{\partial\left(P^{2} / D\right)}{\partial x}+\frac{\partial(P Q / D)}{\partial y}+g D \frac{\partial \varsigma}{\partial x}+\frac{g n^{2}}{D^{7 / 3}} P \sqrt{P^{2}+Q^{2}}+\frac{D}{\rho} \frac{\partial P_{a}}{\partial x}=0 \\
\frac{\partial Q}{\partial t}+\frac{\partial(P Q / D)}{\partial x}+\frac{\partial\left(Q^{2} / D\right)}{\partial y}+g D \frac{\partial \varsigma}{\partial y}+\frac{g n^{2}}{D^{7 / 3}} Q \sqrt{P^{2}+Q^{2}}+\frac{D}{\rho} \frac{\partial P_{a}}{\partial y}=0
\end{gathered}
$$

where $\varsigma$ is water surface elevation from the still water level $(\mathrm{m}), P$ and $Q$ are depth-averaged volume fluxes $\left(\mathrm{m}^{2} / \mathrm{s}\right), g$ is gravity acceleration $\left(\mathrm{m} / \mathrm{s}^{2}\right), D$ is total water depth $(m), \rho$ is the density of water $\left(\mathrm{kg} / \mathrm{m}^{3}\right), n$ is Manning's coefficient $\left(\mathrm{s} / \mathrm{m}^{1 / 3}\right)$, and $\mathrm{m}^{2}$ is air pressure $(\mathrm{hPa})$. The modified nonlinear shallow water equations were solved using the conventional staggered leap-frog finite difference scheme in the new COMCOT model. Subsequently, the modified COMCOT model was employed to simulate the propagation of meteotsunamis over the Yellow Sea.

In general, the nonlinear shallow water models can't capture the dispersive behavior of tsunamis. As a result, numerical models based on shallow water equations (e.g., COMCOT) have been modified to consider physical dispersion of tsunami waves during propagation over the ocean [26]. Those models can consider physical dispersion of tsunami waves using numerical dispersion of a tsunami propagation model to mimic physical dispersion of linear Boussinesq equations. However, the model only calculates physical dispersion during tsunami propagation over the ocean based on linear assumption and nonlinear effects cannot consider simultaneously because of model instability. In this study, we focused on nonlinear effects occurred during propagation of meteotsunamis over the Yellow Sea, such as meteotsunami-tide interaction, generation mechanism of meteotsunamis due to pressure changes, etc., and thus employed the nonlinear shallow equations model of COMCOT.

\subsection{Tide Modeling Configuration}

Oregon State University (OSU) TOPEX/POSEIDON Crossover database (TPXO8) is a recent tidal solution produced using the representer-based variational scheme described by references $[27,28]$ that assimilates altimetry data into a global shallow water model. The TPXO8-atlas solution represents a further refinement that incorporates a series of over 30 regional assimilation solutions to increase the resolution in coastal areas and shallow seas. The base global solution has a resolution of $1 / 6^{\circ}$, with bathymetry for the dynamical model derived from the GEBCO $1^{\circ}$ database. For the nonlinear quarter-diurnal constituents, the two-stage scheme of [29] was used. Regional solutions were obtained with a resolution of $1 / 30^{\circ}$ for 33 rectangular areas, including all major enclosed or semienclosed seas and most coastal areas with a significant continental shelf width [30].

We used the TPXO8 model to predict ocean tidal heights and currents in the Yellow Sea, including the western coast of the Korean Peninsula, at the initial stage of meteotsunami generation, which provided free surface profiles at lateral computational boundaries during numerical modeling of meteotsunami propagation [31]. We have considered every tidal constituent provided by TPXO8 in numerical modeling for better accuracy. Then, the modified COMCOT model was employed to 
simulate variations of tidal height and currents in the Yellow Sea using the initial and boundary conditions obtained from the TPXO8 model.

\subsection{Computational Setup}

The hindcasts of sea level pressure changes over the Yellow Sea were conducted by the atmospheric model WRF using a data assimilation technique. The TPXO8 model was then employed to calculate the initial sea level of each computational grid in the numerical domain and to provide outward boundary conditions of the numerical domain corresponding to numerical modeling of meteotsunamis. Lastly, the modified COMCOT model simulated hydrodynamic processes in the Yellow Sea from the source of the atmospheric pressure forcing and reproduced two cases of meteotsunamis in the Yellow Sea. The COMCOT model has been employed to study complex transformations of meteorological tsunamis in the Yellow Sea, accounting for depth-induced refraction, diffraction, and shoaling effects. In general, the Boussinesq models based on superior governing equations considering dispersive behavior of wave motions as well as nonlinear effects, have been shown better performance in many coastal problems. However, for tsunami modeling over the ocean, the Boussinesq models sometimes show numerical instability as simulation time increases. In this study, we should have applied a numerical model to calculate propagation of meteotsunamis over the Yellow Sea for a very long simulation time to conduct tide modeling with generation of meteotsunamis simultaneously. Furthermore, for tide modeling and generation of meteotsunamis due to pressure changes, we have modified the source code of COMCOT, in calculation of the boundary conditions and convection terms. This modification would be highly complicated for Boussinesq models and unexpected numerical errors can occur and increase during computation, though such changes would be relatively straightforward for COMCOT. Consequently, COMOT, a well-known nonlinear shallow water equations model, was modified and employed to calculate generation and amplification of meteotsunamis over the Yellow Sea for a very long simulation time. The nonlinear shallow water equations model can cause a slight decrease in accuracy, but provide much better model stability.

The computational grid was constructed by utilizing 30 arc-second KorBathy30s bathymetry data [32], 1 arc-minute global relief model ETOPO1 bathymetry data, and the electronic navigational charts produced by the Korea Hydrographic and Oceanographic Administration (KHOA). Resolution of the grid system was built as $1001 \times 901$ (33-42 N, 117-127 E) and a uniform grid of 0.6 min was used in each latitudinal and longitudinal direction.

\section{Experimental Cases}

\subsection{Meteotsunami in the Yellow Sea (31 March 2007)}

A meteotsunami occurred in the Yellow Sea on 31 March 2007, which caused unexpected extreme waves in the middle of the Yellow Sea towards to the western coast of the Korean Peninsula. Those waves propagated over the Yellow Sea and resulted in some casualties and property damage along the western coast of the Korean Peninsula. According to previous studies, the maximum wave height of the meteotsunami was recorded to be approximately $1.4 \mathrm{~m}$ high at the Yeonggwang Tidal Station and high run-up was observed in many other tidal stations. Additional damage was also reported in coastal areas due to the inundation. Since the tidal condition of the Yeonggwang region was during a flood tide, it could be assumed that the damage was caused by the coincidental overlapping of the flood tide and the meteorological tsunami [7].

Figure 2 summarizes the location of the Automatic Weather Stations (AWSs) operated by the Korea Meteorological Administration (KMA) and the tidal stations operated by KHOA. The abbreviation for different station locations can be found in Table 2. [7] analyzed the available observed atmospheric pressure data and identified the arrival timings of the pressure jump during the meteotsunami that occurred on 31 March 2007. Figure 3 shows the contour lines over the Korean Peninsula with the same or similar arrival timings as the pressure jump [7]. The broken lines, which were advisedly estimated 
by analyzing the profiles of observed pressure data, represent particular time lines of linked pressure jump points and thus show propagation of the atmospheric pressure jump over the Korean Peninsula.

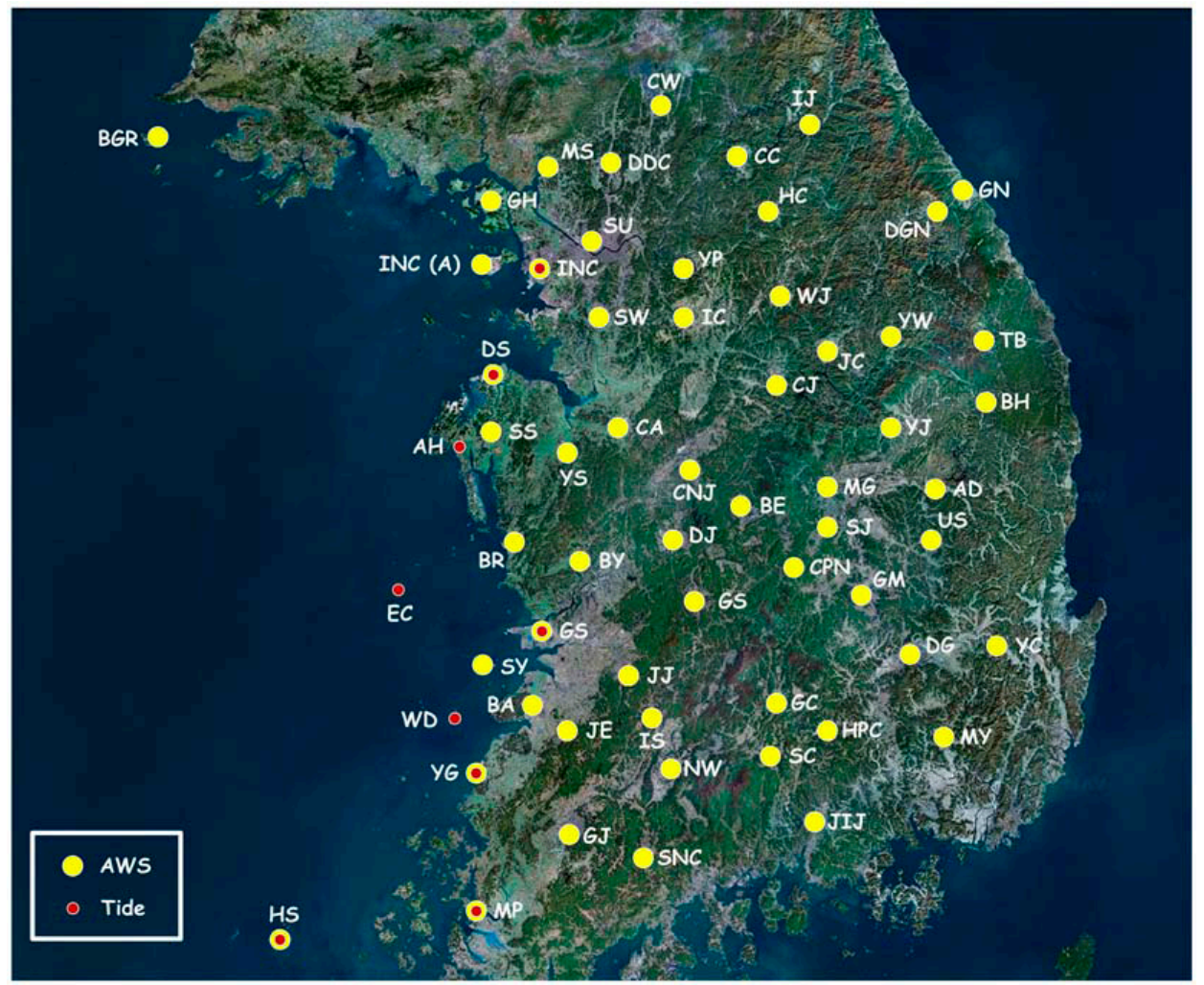

Figure 2. Location of the automatic weather stations (AWSs) and the tidal stations.

Table 2. Abbreviation of AWSs and tide stations.

\begin{tabular}{cccccc}
\hline Station & Abbreviation & Station & Abbreviation & Station & Abbreviation \\
\hline Andong & AD & Gangneung & GN & Moonsan & MS \\
Anheung & AH & Geochang & GC & Mungyeong & MG \\
Baegryeong & BGR & Geumsan & GS & Namwon & NW \\
Boeun & BE & Gumi & GM & Sancheong & SC \\
Bonghwa & BH & Gunsan & GS & Sangju & SJ \\
Boryeong & BR & Gwangju & GJ & Seonyu & SY \\
Buan & BA & Hapcheon & HPC & Seosan & SS \\
Buyeo & BY & Heuksan & HS & Seoul & SU \\
Cheonan & CA & Hongcheon & HC & Suncheon & SNC \\
Cheongju & CNJ & Icheon & IC & Suwon & SW \\
Cheorwon & CW & Imsil & IS & Taebaek & TB \\
Chuncheon & CC & Incheon & INC (A) & Uiseong & US \\
Chungju & CJ & Incheon & INC & Wido & WD \\
Chupungnyeong & CPN & Inje & IJ & Wonju & WJ \\
Daegu & DG & Jecheon & JC & Yangpyeong & YP \\
Daegwalnyeong & DGN & Jeongeup & JE & Yeongcheon & YC \\
Daejeon & DJ & Jeonju & JJ & Yeonggwang & YG \\
Daesan & DS & Jinju & JIJ & Yeongju & YJ \\
Dongducheon & DDC & Milyang & MY & Yeongwol & YW \\
Eocheong & EC & Mokpo & MP & Yesan & YS \\
Ganghwa & GH & & & & \\
\hline & & & &
\end{tabular}




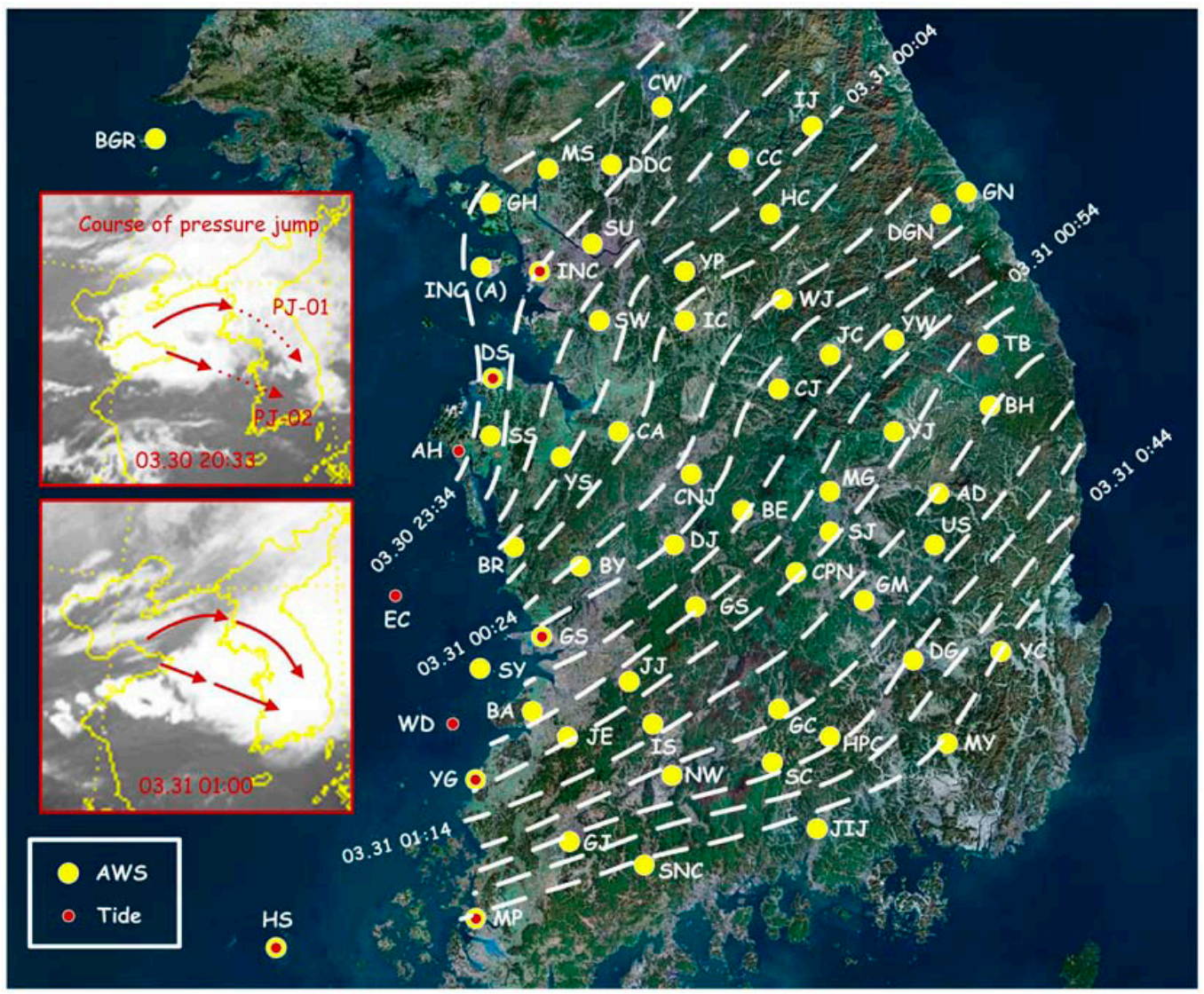

Figure 3. Distribution of pressure jump lines according to arrival time during the meteotsunami that occurred in March 2007 [7].

The path of the pressure jump was also analyzed in reference [7] using satellite images and, consequently, the horizontal distribution of atmospheric pressure jumps propagated over the Yellow Sea was estimated (Figure 4). In Figure 4, the symbol ( $\Delta$, triangle) indicates the travel distances of the air pressure jump, which headed for Anheung, Baegryeong, Gunsan, Incheon, and Yeonggwang according to the distance at each time that was analyzed by reference [7]. The broken lines represent assumed time lines linking the pressure jump point with the same particular time and thus show the distribution of the atmospheric pressure jumps propagated over the Yellow Sea. The atmospheric pressure jump headed for Baegryeong, Incheon, and Anheung seems to have an arc shape that is moving toward the east. The pressure jump headed for Anheung, Gunsan, and Yeonggwang seems to be rotated approximately $40^{\circ}$ clockwise and progressing toward the southeast. Our hindcasts of the sea level pressure changes over the Yellow Sea were compared with Bae's estimation and agree well with the estimation. For tidal effects and qualitative analysis, numerical results are discussed in detail in the results section. 


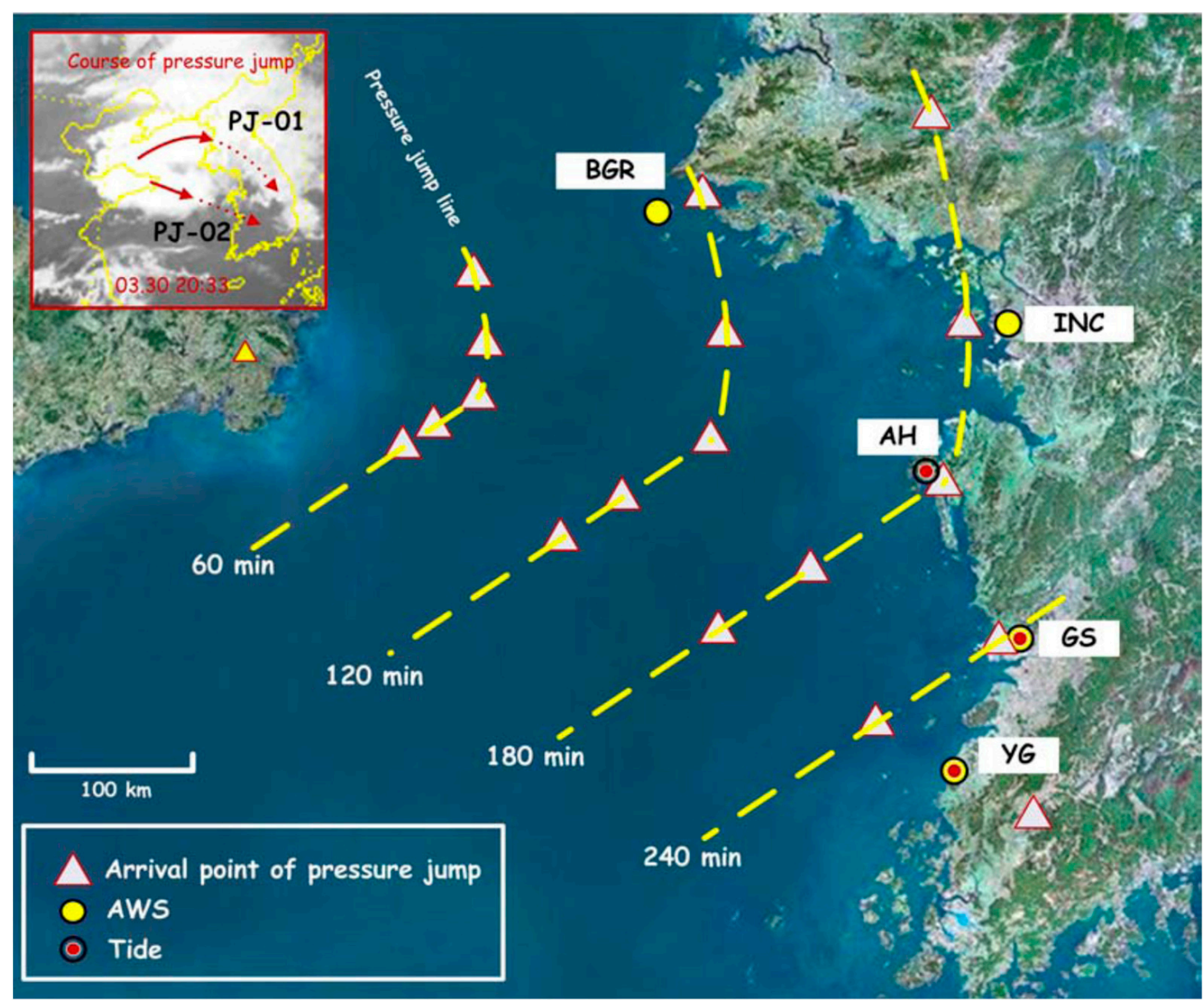

Figure 4. Estimation of the traveling path of the pressure jump over the Yellow Sea during the meteotsunami that occurred in March 2007 [7].

\subsection{Meteotsunami in the Yellow Sea (4 May 2008)}

On 4 May 2008, a meteorological tsunami occurred in the Yellow Sea, and abnormally extreme waves were observed at Jukdo Island, located on the western coast of Boryeong, Korea [12,33]. The event attracted the attention of many engineers and scientists because it caused extreme waves only at Jukdo Island, unlike the previous meteorological tsunami that occurred in 2007, which caused abnormally extreme waves along the western coast of Korea. In general, a meteotsunami can be forecasted using large-scale meteorological observation data and climate modeling systems. However, a small-scale meteorological tsunami, such as the 2008 event, should be analyzed using a high-resolution modeling system because water motions can be affected by local terrain, which can cause abnormally extreme waves only in the specific coastal area [12].

Ref. [9] analyzed the observed wave data for the 2008 tsunami and obtained a time series of the significant wave heights and periods to identify the influence of wind waves, but the wind waves were observed to only increase the wave heights a day after the event. They also analyzed the automatic weather system data and weather radar images and observed that the pressure jump moved from the southwest to the northeast at a speed of approximately $23.0 \mathrm{~m} / \mathrm{s}$ on average and that the mean magnitude of the pressure jump was $1-3 \mathrm{hPa}$. Figure 5 shows the variation in precipitation concentration in radar data from 10:00 a.m. to 12:30 p.m. on 4 May 2008. The moving atmospheric pressure disturbance, indicated by blue ellipses, is clearly displayed in Figure 5 [9,10,12]. In general, the mean water depth is approximately $44.0 \mathrm{~m}$ in the Yellow Sea and long-period waves can move at a speed of $\mathrm{c}=\sqrt{\mathrm{gh}} 20.98 \mathrm{~m} / \mathrm{s}$ with the pressure jump. Thus, a long-period sea wave generated by local scale pressure jumps might be amplified during propagation owing to the Proudman resonance. 
In this case, the wave heights would be $5.0-10.0 \mathrm{~cm}$, since the amplification is generally multiplied by up to five times when compared with the air pressure change. The predicted wave heights agree well with observational data collected from national tidal stations and temporary wave stations. However, the abnormal oscillation observed at Jukdo Island is exceptional, and it might have originated from certain local conditions, such as rapid variations in topography [12].
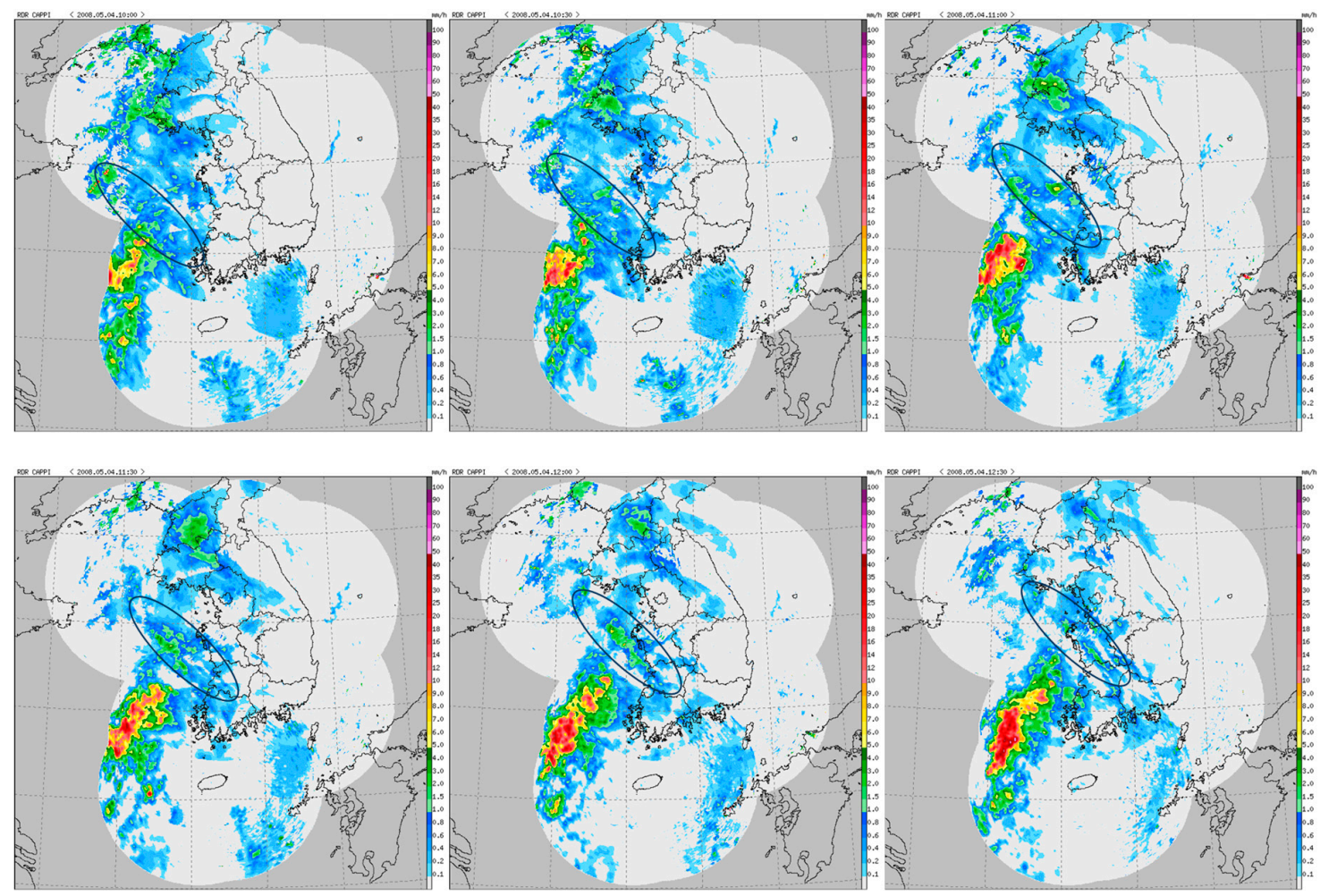

Figure 5. Moving atmospheric pressure disturbance observed in weather radar images (KMA) from 10:00 a.m. (LST) to 12:30 p.m. (LST) on 4 May 2008.

Ref. [7] analyzed the available infrared images observed through the Multifunctional Transport Satellite (MTSAT) of Japan during the meteotsunami that occurred on 4 May 2008 and assumed the path of the pressure jump using the satellite images [7]. Then, reference [7] represented the arrival time of the pressure jump as contour lines (Figure 6). The dashed lines indicate the location at which the pressure jumps arrived simultaneously. The interval of each pressure jump line was set to be $10 \mathrm{~min}$. The two pressure jump lines at 1:10 p.m. (KST) and 2:00 p.m. (KST) on 4 May, which are shown as a dash-dot-dot line in Figure 6, were interpolated based on the other contour lines. It is clear that the pressure jump lines propagated from the southwest to the northeast. In particular, reference [7] identified that the moving path of the pressure jump shown in Figure 6 had a very similar shape to the path estimated by analyzing the corresponding infrared images of MTSAT. Our hindcasts of the sea level pressure changes over the Yellow Sea were also compared with Bae's estimation, and tidal effects on the behavior of the meteotsunami are discussed in detail in the next section. 


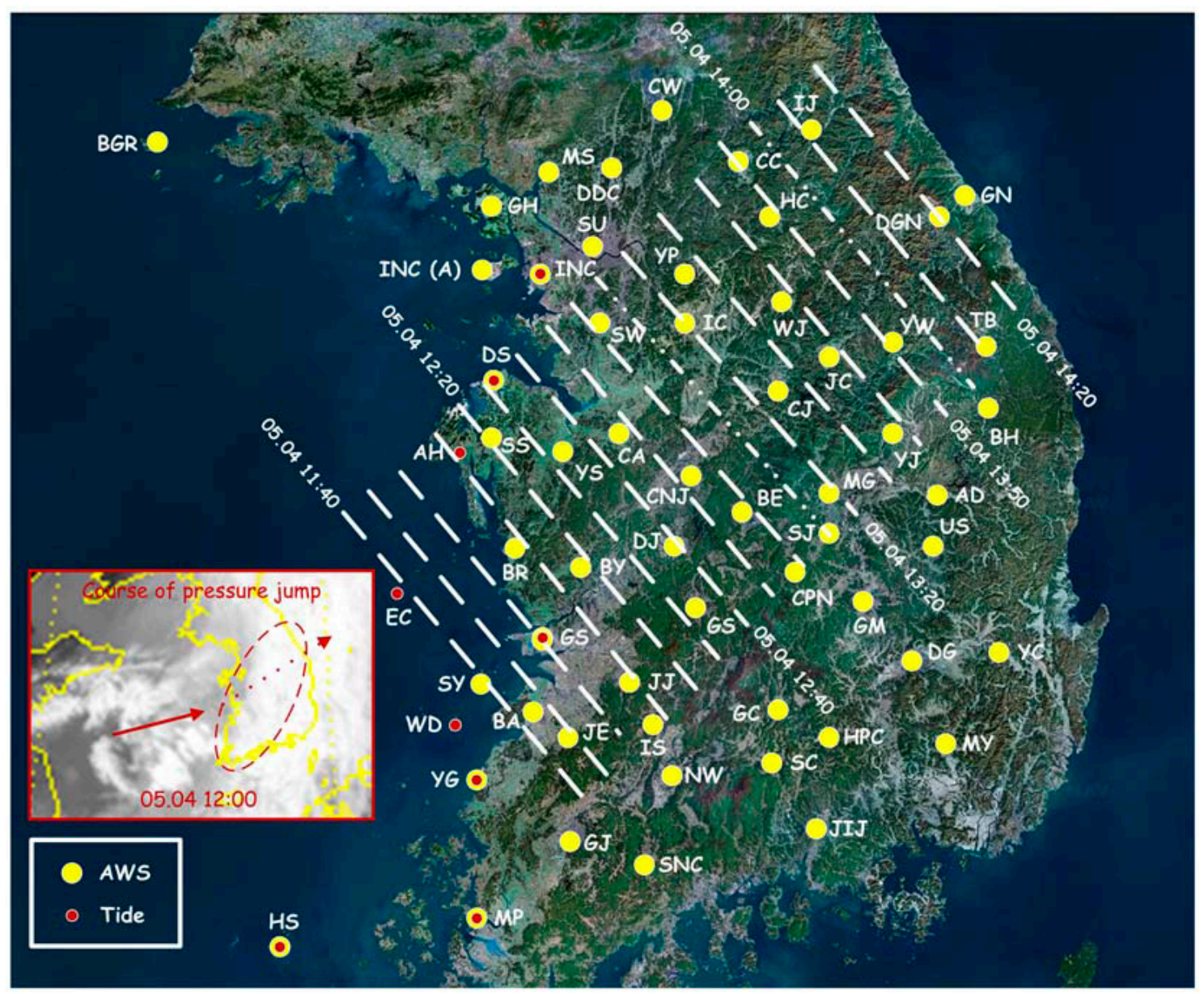

Figure 6. Distribution of pressure jump lines according to arrival time during the meteotsunami that occurred in May 2008 [7].

\section{Results and Discussion}

\subsection{Numerical Simulation of a Meteotsunami (31 March 2007)}

In this study, the generation and propagation of the meteotsunami that occurred on 31 March 2007 was simulated using the WRF and COMCOT models over the Yellow Sea. First, we simulated a meteotsunami only, without tide modeling, to identify the generation process of a meteotsunami in detail. Figure 7 shows free surface displacements and sea level pressure changes over the Yellow Sea during the meteotsunami that occurred in 2007. Regarding sea level pressure changes, the distribution of pressure jump lines was clearly seen and the numerical results were quite agreeable with Bae's estimation shown in Figure 4. Figure 3 suggested that the western coast of the Korean Peninsula was affected by two different sources of atmospheric pressure disturbance, and the numerical results of sea level pressure distribution confirmed this implication (Figure 7). As shown in the figures, the atmospheric pressure jump line first developed at the northwestern part of the Yellow Sea and then divided into two parts during propagation over the Yellow Sea. As a result, the distribution of the free surface displacements showed that high waves developed widely during the event and lasted until 2:00 a.m. LST. The numerical results of the free surface displacement distribution qualitatively reproduced the event well, however, wave heights were relatively small compared with the observational data. Since the resolution of the grid system was approximately $1 \mathrm{~km}$, nonlinear effects originated by atmospheric pressure disturbance may not have been sufficiently considered, thus causing the discrepancy. 


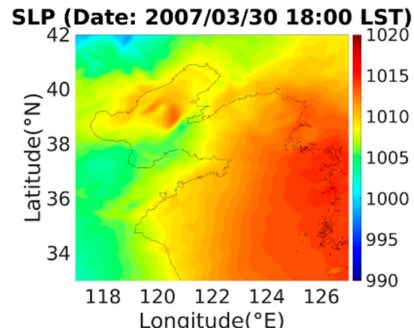

FSD (Date: 2007/03/30 18:00 LST)

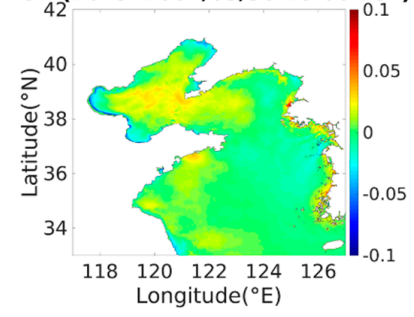

(a) $2007 / 03 / 301800$ LST

SLP (Date: 2007/03/30 21:00 LST)

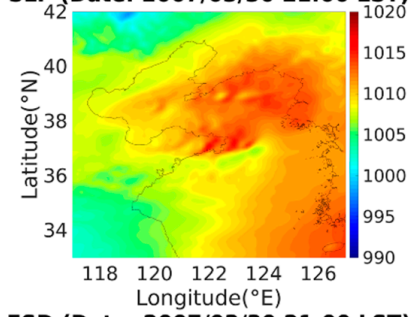

FSD (Date: 2007/03/30 21:00 LST)

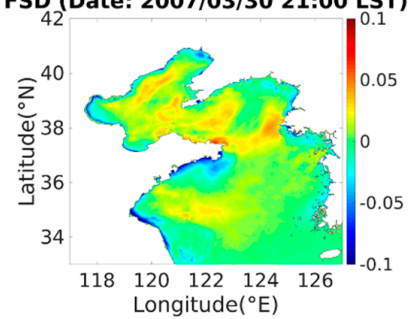

(d) $2007 / 03 / 302100$ LST

SLP (Date: 2007/03/31 00:00 LST)

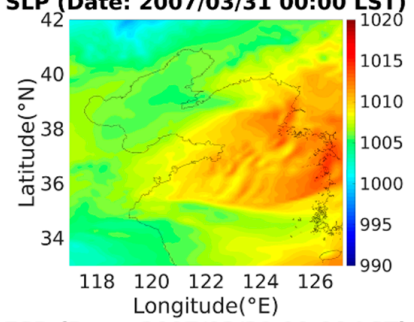

FSD (Date: 2007/03/31 00:00 LST)

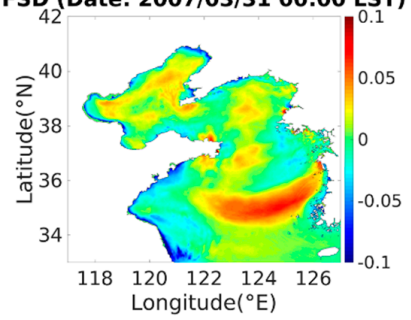

(g) 2007/03/31 0000 LST

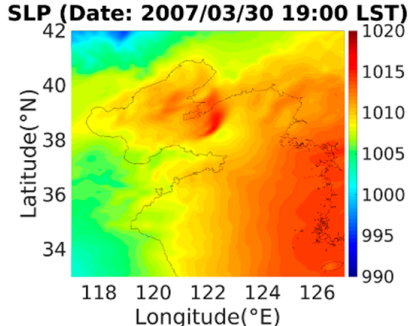

FSD (Date: 2007/03/30 19:00 LST)

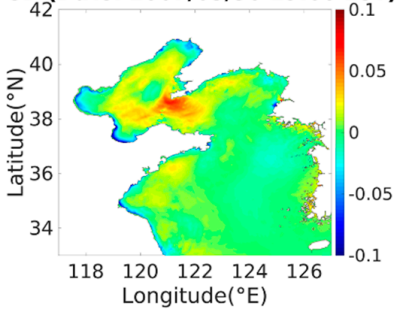

(b) 2007/03/30 1900 LST

SLP (Date: 2007/03/30 22:00 LST)

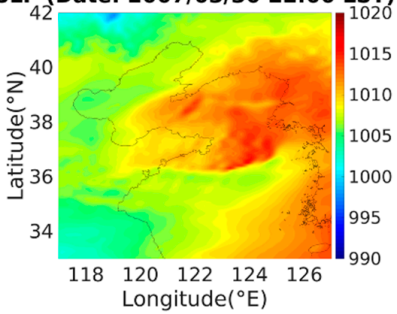

FSD (Date: 2007/03/30 22:00 LST)

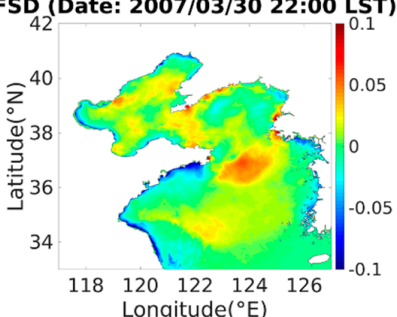

(e) 2007/03/30 2200 LST

SLP (Date: 2007/03/31 01:00 LST)

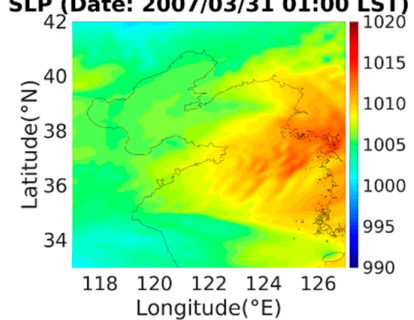

FSD (Date: 2007/03/31 01:00 LST)

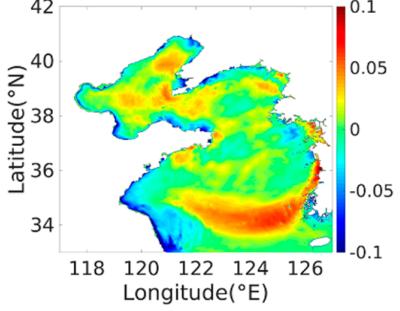

(h) 2007/03/31 0100 LST

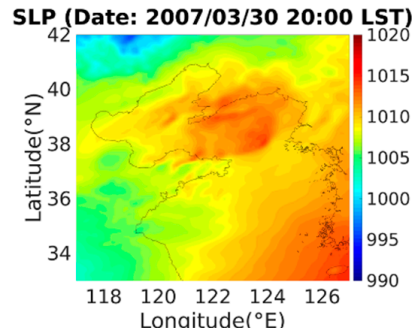

FSD (Date: 2007/03/30 20:00 LST)

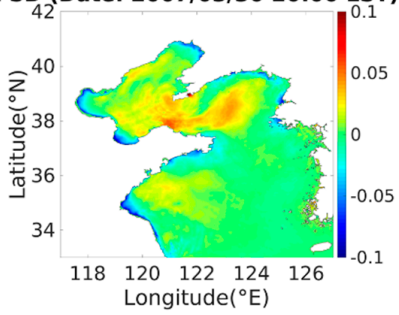

(c) 2007/03/30 2000 LST

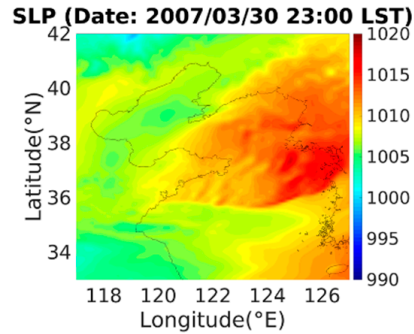

FSD (Date: 2007/03/30 23:00 LST)

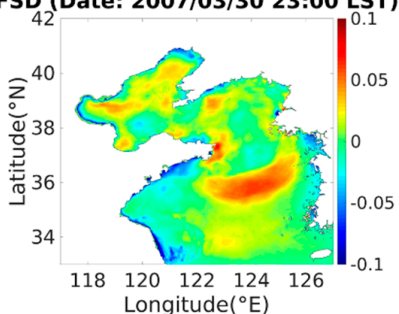

(f) 2007/03/30 2300 LST

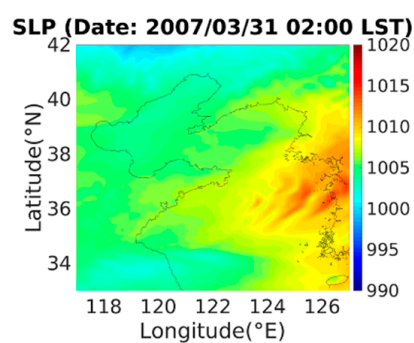

FSD (Date: 2007/03/31 02:00 LST)

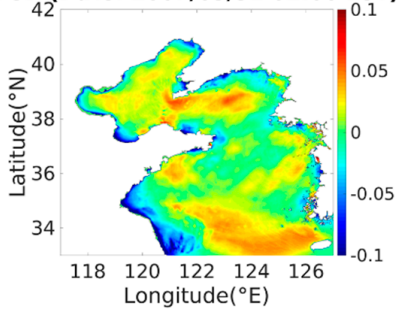

(i) $2007 / 03 / 310200$ LST

Figure 7. The free surface displacement (FSD, bottom) and sea level pressure (SLP, above) change in the Yellow Sea during the meteotsunami that occurred in March 2007. (a) 1800 LST 30 Mar 2007; (b) 1900 LST 30 Mar 2007; (c) 2000 LST 30 Mar 2007; (d) 2100 LST 30 Mar 2007; (e) 2200 LST 30 Mar 2007; (f) 2300 LST 30 Mar 2007; (g) 0000 LST 31 Mar 2007; (h) 0100 LST 31 Mar 2007; (i) 0200 LST 31 Mar 2007. 
Next, we simulated the whole transformation process of a meteotsunami along with tide modeling to consider the interaction between a meteotsunami and tidal currents. Since the nonlinear interaction can play a significant role in the propagation and amplification process of a meteotsunami, the propagation pattern of a meteotsunami over the Yellow Sea was compared with and without tide modeling at each corresponding time step. Figure 8 shows the comparison of the free surface displacements computed with tide modeling during the meteotsunami. Figure 8a represents the transformation of the meteotsunami with tide modeling, while Figure $8 \mathbf{b}$ shows tide modeling only. Figure $8 \mathrm{c}$ represents the differences of the computed free surface displacement between the meteotsunami with tide modeling and tide modeling only. At the initial stage, the generation process of the meteotsunami was quite similar to that without tide modeling, and amplification process was initiated from the northwestern part of the Yellow Sea. Since tidal currents were very powerful compared with the wave heights of the meteotsunami, Figure 8a,b show almost the same distribution pattern of free surface displacements at the initial stage. On the other hand, tidal currents developed toward the northwest in the vicinity of the northwestern part of the Korean Peninsula and had a negative effect on the generation process of the meteotsunami. As a result, amplification of the meteotsunami was diminished, and Figure $8 \mathrm{c}$ shows relatively small wave heights compared with those without tide modeling (Figure 7).

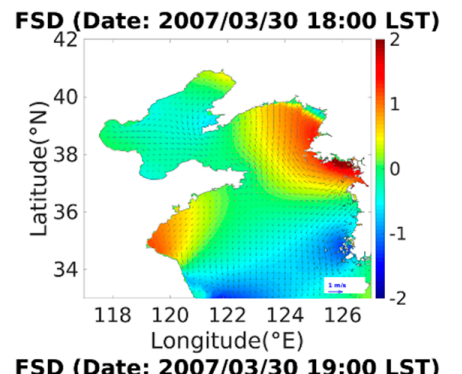

FSD (Date: 2007/03/30 19:00 LST)
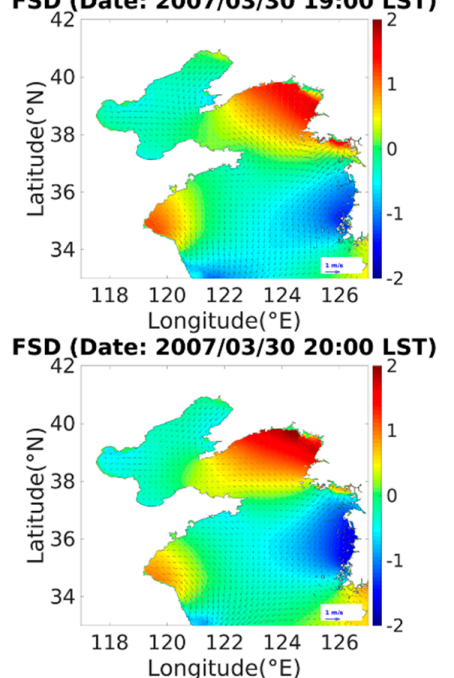

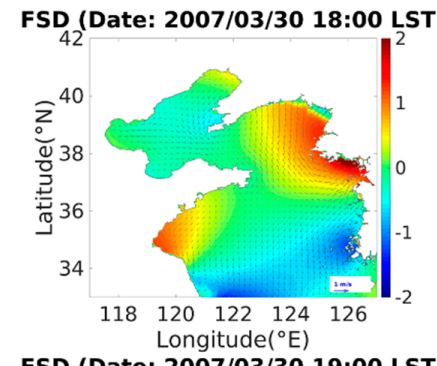

FSD (Date: 2007/03/30 19:00 LST)

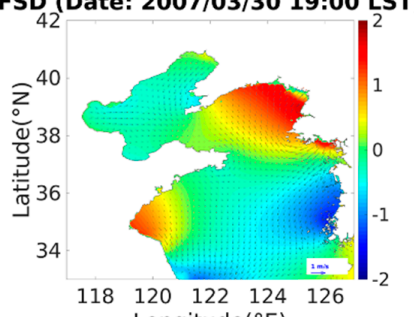

Longitude $\left({ }^{\circ} \mathrm{E}\right)$

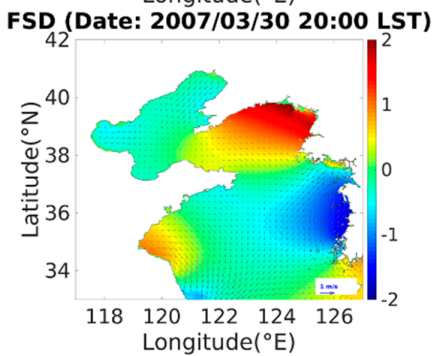

Figure 8. Cont.
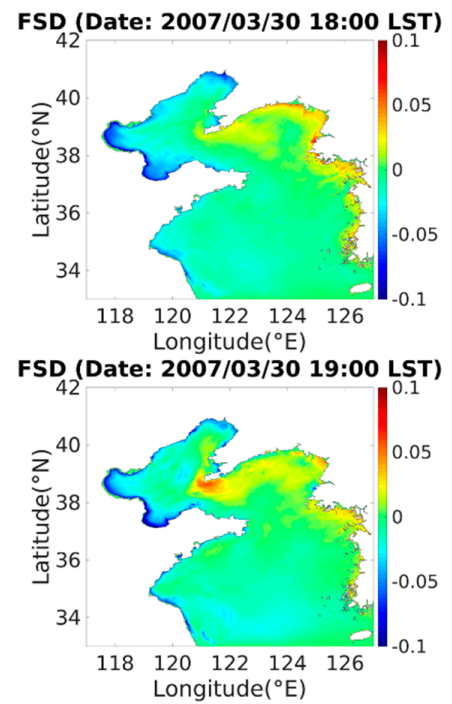

FSD (Date: 2007/03/30 20:00 LST)

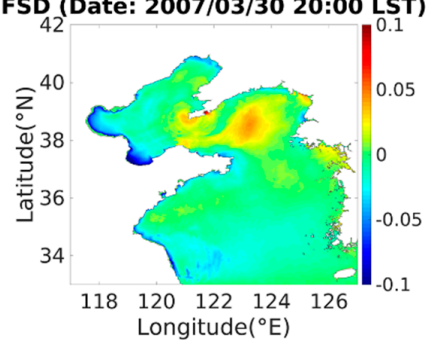




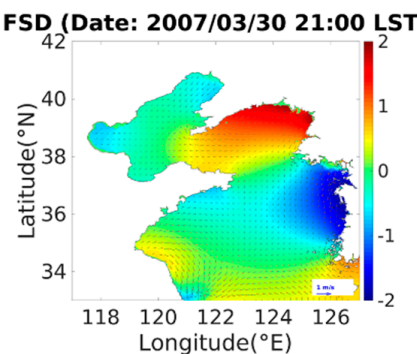

FSD (Date: 2007/03/30 22:00 LST)

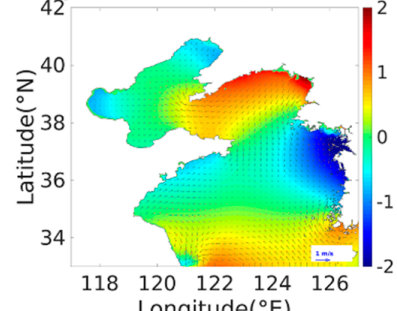

FSD (Date: 2007/03/30 23:00 LST)

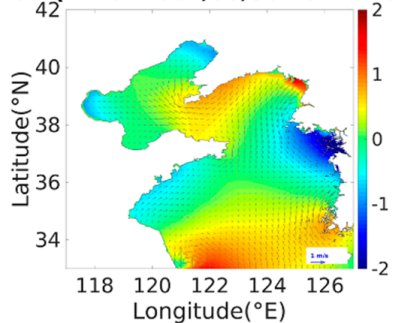

FSD (Date: 2007/03/31 00:00 LST)

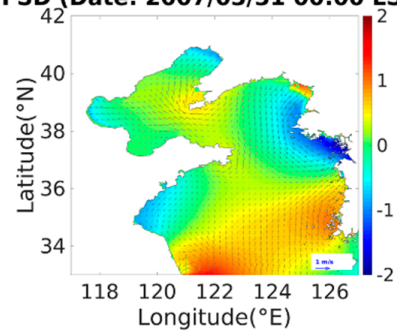

FSD (Date: 2007/03/31 01:00 LST)

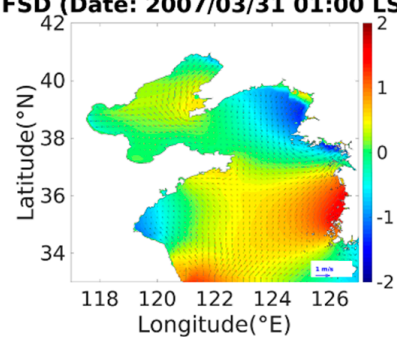

FSD (Date: 2007/03/31 02:00 LST)

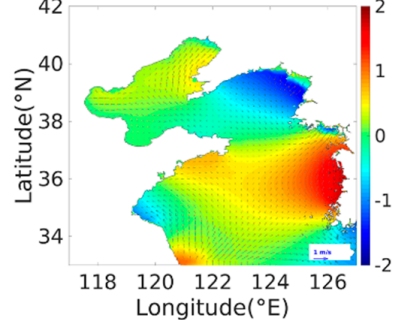

(a) Meteotsunami + Tide

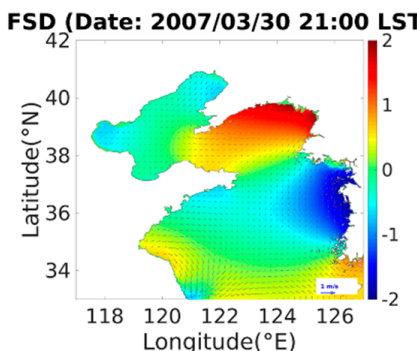

FSD (Date: 2007/03/30 22:00 LST)

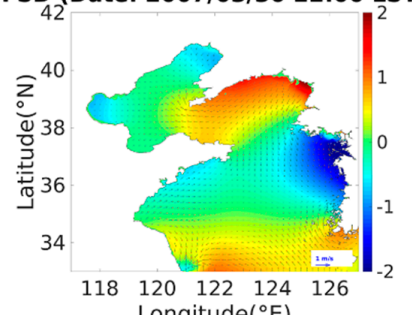

FSD (Date: 2007/03/30 23:00 LST)

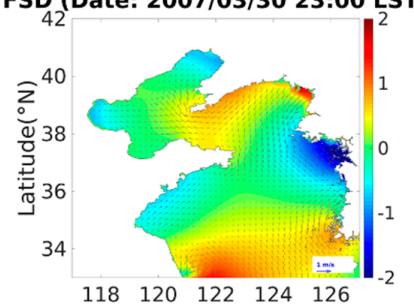

$\begin{array}{llll}118 & 120 & 122 & 124 \\ & \text { Longitude }\left({ }^{\circ} \mathrm{E}\right)\end{array}$

FSD (Date: 2007/03/31 00:00 LST)

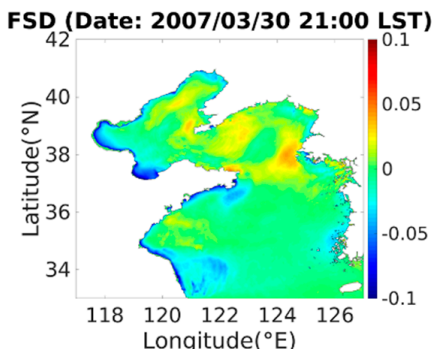

FSD (Date: 2007/03/30 22:00 LST)

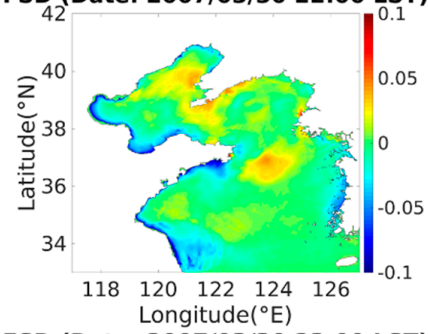

FSD (Date: 2007/03/30 23:00 LST)

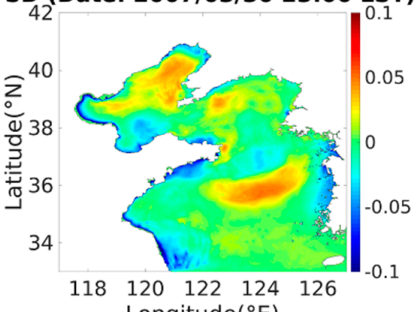

Longitude $\left({ }^{\circ} \mathrm{E}\right)$

FSD (Date: 2007/03/31 00:00 LST)

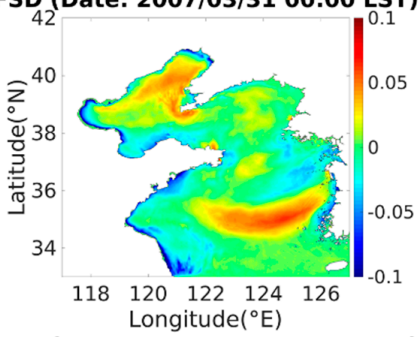

FSD (Date: 2007/03/31 01:00 LST)

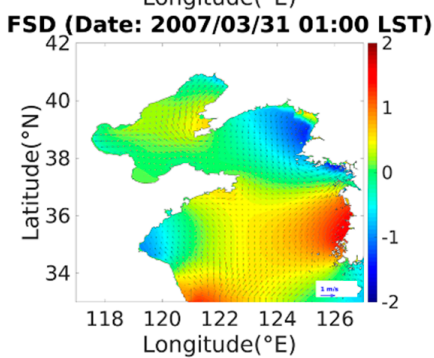

FSD (Date: 2007/03/31 02:00 LST)

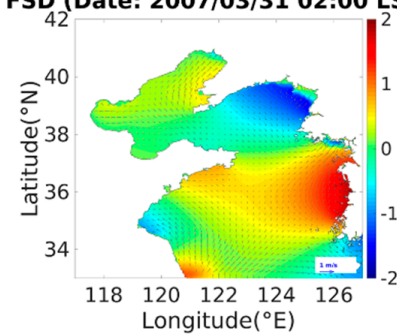

(b) Tide only

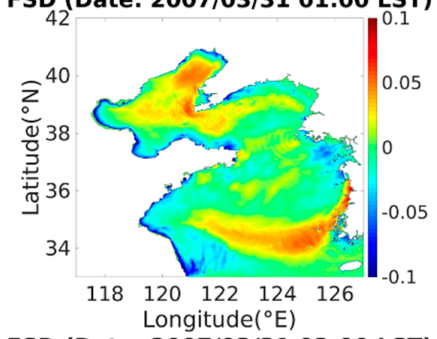

FSD (Date: 2007/03/31 02:00 LST)

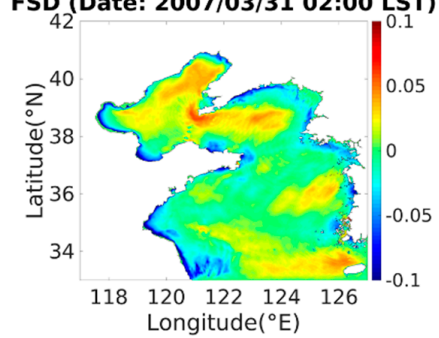

(c) Meteotsunami only

Figure 8. Comparison of the free surface displacement (FSD) change with tide modeling in the Yellow Sea during the meteotsunami that occurred in March 2007. (a) FSD change of the meteotsunami with tide modeling; (b) FSD change of tides; (c) FSD change of the meteotsunami only. 
The effects of tidal currents were further increased as the meteotsunami propagated over the Yellow Sea during the event. Figure 8a shows a somewhat different distribution of amplification that was slightly higher than that of tide only modeling shown in Figure 8b. As the meteotsunami propagated along the western coast of the Korean Peninsula, the meteotsunami advanced and amplified in the direction of the southeast, while tidal currents were toward the direction of the north and northeast. On the other hand, tidal currents were toward the northwest in the vicinity of the Liaodong Peninsula and had a positive effect on the development of the meteotsunami. Consequently, the amplification process of the meteotsunami was diminished in the vicinity of the Korean Peninsula, and Figure 8c represents the relatively small wave heights compared with those without tide modeling in Figure 7 , while wave heights were slightly higher than those without tide modeling in the vicinity of the Liaodong Peninsula.

\subsection{Numerical Simulation of a Meteotsunami (4 May 2008)}

The propagation of the meteotsunami that occurred on 4 May 2008 was simulated using the WRF and COMCOT models over the Yellow Sea. First, we simulated a meteotsunami only without tide modeling to identify the generation process of the meteotsunami in detail. Figure 9 shows free surface displacements and sea level pressure changes over the Yellow Sea during the meteotsunami. Unlike the previous event, there was no clear sign of pressure jump line propagation in sea level pressure changes, but a brief atmospheric pressure disturbance developed in the middle of the Yellow Sea. The atmospheric pressure disturbance first developed along the eastern coast of China and divided into two parts at the southwestern and eastern directions in the vicinity of the Korean Peninsula. Numerical results of sea level pressure distribution suggest that this brief pressure jump line caused the local effect on the western coast of the Korean Peninsula during the event. Reference [7] approximately estimated the propagation of pressure jump lines based on land observational data (Figure 6). The numerical results of sea level pressure distribution confirmed the implication and a more detailed description may be obtained with high-resolution numerical modeling. Numerical results of the free surface displacement distribution qualitatively reproduced the event well; however, wave heights were relatively small compared with the observational data overall. Since the event was a small-scale meteotsunami, the grid system may not have been sufficient to consider nonlinear effects and variable topographies. Also, wind effects were not considered in the numerical modeling, which are the main sources of high wave development, so the discrepancy may have been caused by the lack of those sources $[12,13]$. 


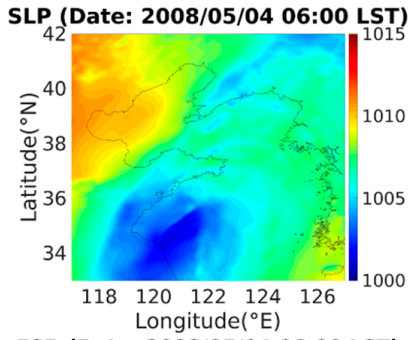

FSP (Date: 2008/05/04 06:00 LST)

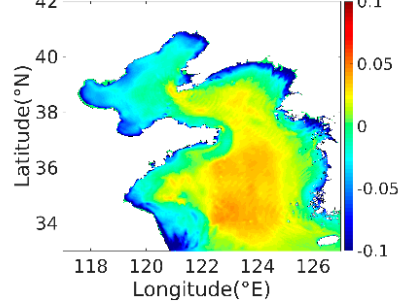

(a) 2008/05/04 0600 LST

SLP (Date: 2008/05/04 09:00 LST)

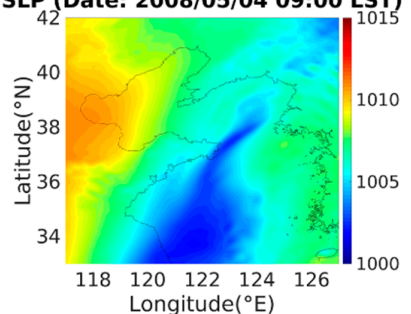

FSP (Date: 2008/05/04 09:00 LST)

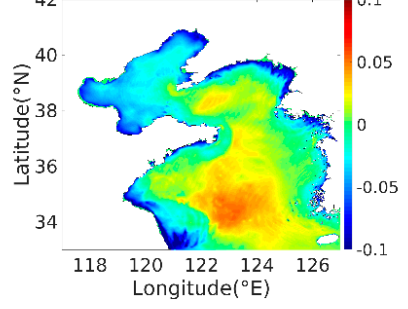

(d) 2008/05/04 0900 LST

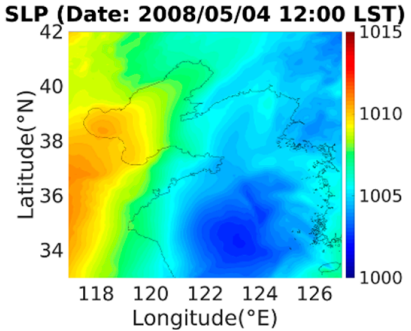

FSP (Date: 2008/05/04 12:00 LST)

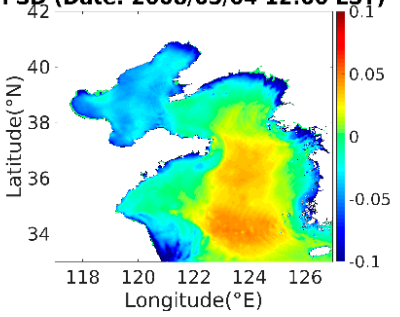

(g) 2008/05/04 1200 LST

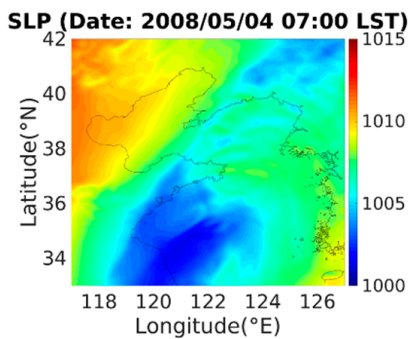

FSP (Date: 2008/05/04 07:00 LST)

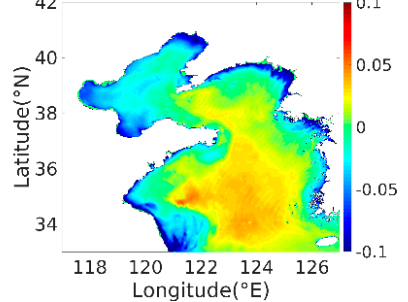

(b) 2008/05/04 0700 LST

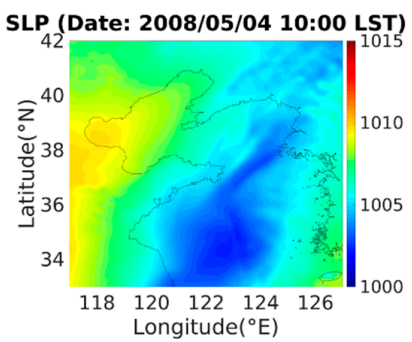

FSP (Date: 2008/05/04 10:00 LST)

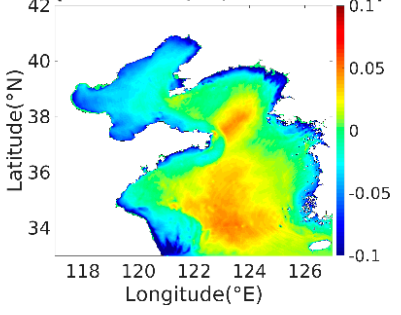

(e) 2008/05/04 1000 LST

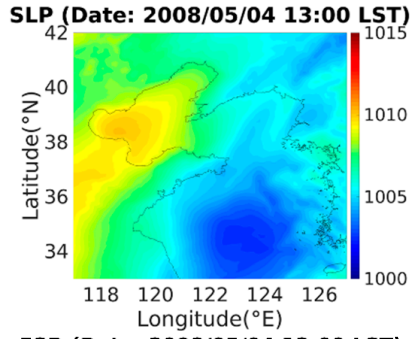

FSP (Date: 2008/05/04 13:00 LST)

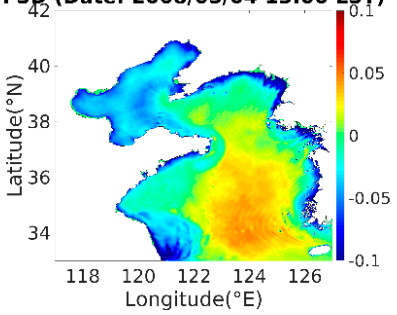

(h) 2008/05/04 1300 LST

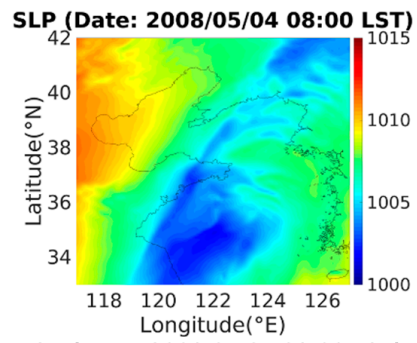

FSP (Date: 2008/05/04 08:00 LST)

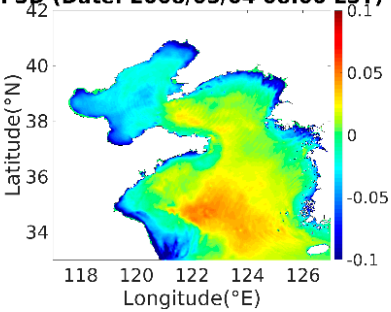

(c) 2008/05/04 0800 LST

SLP (Date: 2008/05/04 11:00 LST)

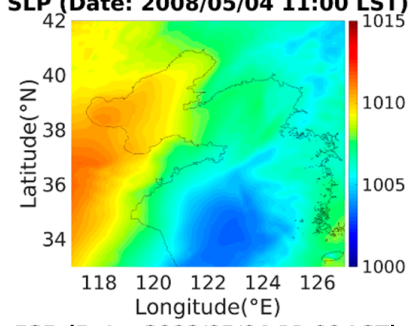

FSP (Date: 2008/05/04 11:00 LST)

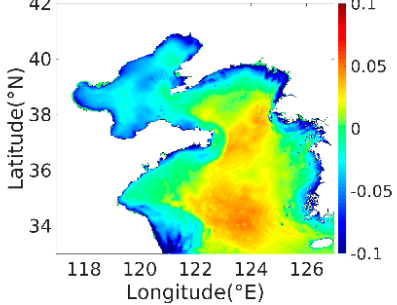

(f) 2008/05/04 1100 LST

SLP (Date: 2008/05/04 14:00 LST)

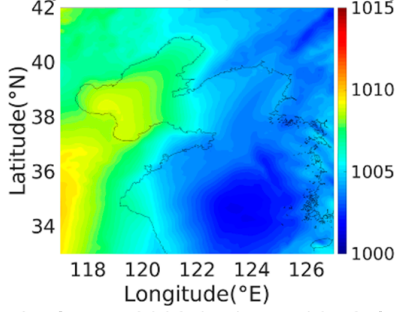

FSP (Date: 2008/05/04 14:00 LST)

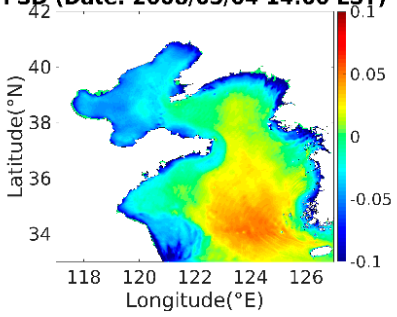

(i) $2008 / 05 / 041400$ LST

Figure 9. The free surface displacement (FSD, bottom) and sea level pressure (SLP, above) change in the Yellow Sea during the meteotsunami that occurred in May 2008. (a) 0600 LST 4 May 2008; (b) 0700 LST 4 May 2008; (c) 0800 LST 4 May 2008; (d) 0900 LST 4 May 2008; (e) 1000 LST 4 May 2008; (f) 1100 LST 4 May 2008; (g) 1200 LST 4 May 2008; (h) 1300 LST 4 May 2008; (i) 1400 LST 4 May 2008. 
The transformation of a meteotsunami, generated and propagated over the Yellow Sea in May 2008, was calculated considering the interaction between a meteotsunami and tidal currents. Figure 10 shows a comparison of the free surface displacements computed with tide modeling during the meteotsunami. Figure 10a represents the transformation of the meteotsunami with tide modeling, while Figure 10b shows tide modeling only. Figure 10c represents differences of computed free surface displacement between the meteotsunami with tide modeling and tide modeling only. As shown in Figure 9, the computed sea level pressure showed a brief pressure jump line from the northwest toward the southeast at 9:00 a.m. LST, and low pressure slowly developed and propagated from the southwestern part of the Yellow Sea toward the Korean Peninsula. These two parts of the pressure conditions may have contributed to the brief generation of a meteotsunami. However, the amplification process only appeared briefly in the middle of the Yellow Sea, and the abnormally high wave observed at Jukdo Island hardly registered in the numerical results. Like the previous 2007 case, the generation process of the meteotsunami was quite similar, with or without tide modeling. Figure 10a,b show almost the same distribution pattern of free surface displacements at the initial stage, since tidal currents were very powerful compared with the wave heights of the meteotsunami. On the other hand, tidal currents developed toward the northwest and the north in the vicinity of the western coast of the Korean Peninsula and had a negative effect on the generation process of the meteotsunami near the northeastern sea of the Shandong Peninsula. Further, tidal currents in the southeastern sea of the Shandong Peninsula were directed to the south and had a negative effect on the generation process of the meteotsunami. As a result, amplification of the meteotsunami was diminished and Figure 10c shows relatively small wave heights compared with those without tide modeling in Figure 9 at the initial stage.

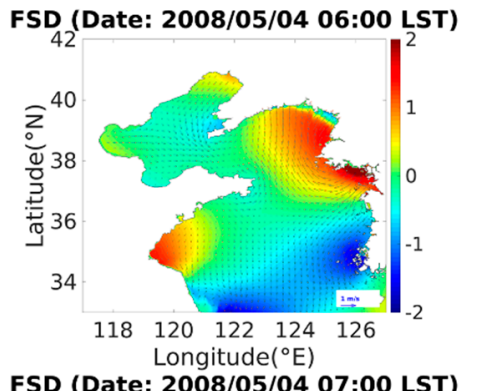

FSD (Date: 2008/05/04 07:00 LST)

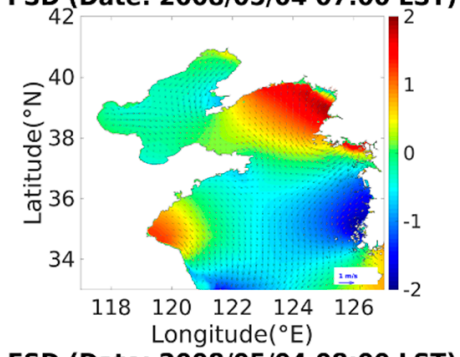

FSD (Date: 2008/05/04 08:00 LST)

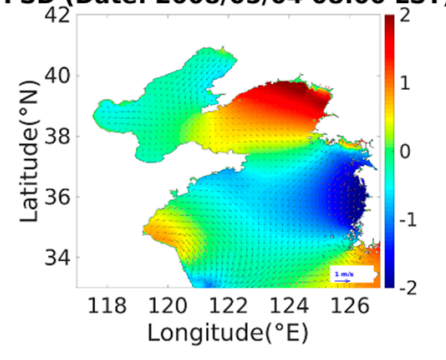

FSD (Date: 2008/05/04 06:00 LST)

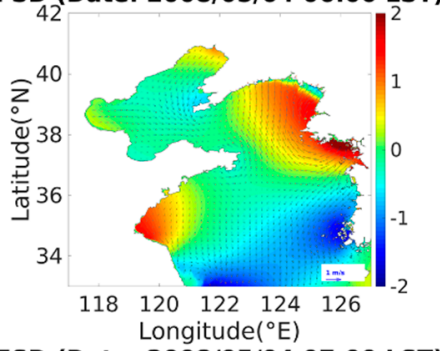

FSD (Date: 2008/05/04 07:00 LST)

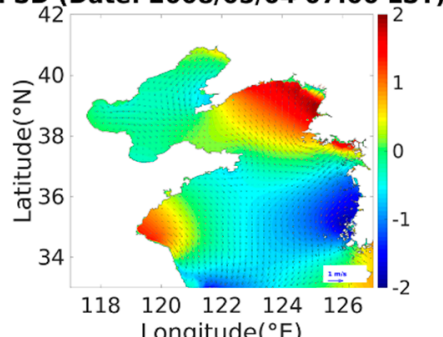

Longitude $\left({ }^{\circ} \mathrm{E}\right)$

FSD (Date: 2008/05/04 08:00 LST)

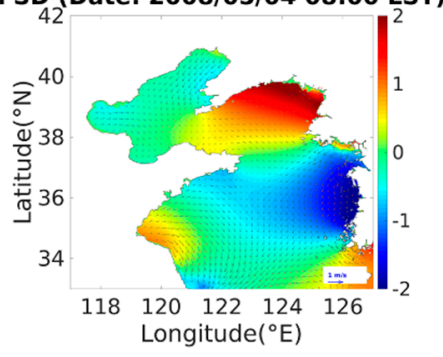

Figure 10. Cont.
FSD (Date: 2008/05/04 06:00 LST)

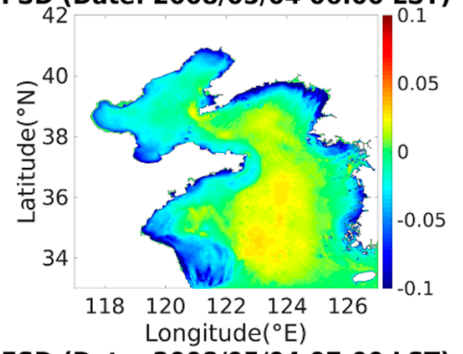

FSD (Date: 2008/05/04 07:00 LST)

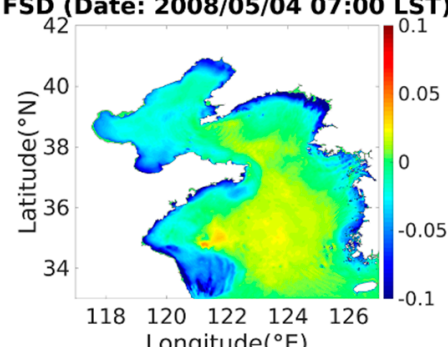

Longitude $\left({ }^{\circ} \mathrm{E}\right)$

FSD (Date: 2008/05/04 08:00 LST)

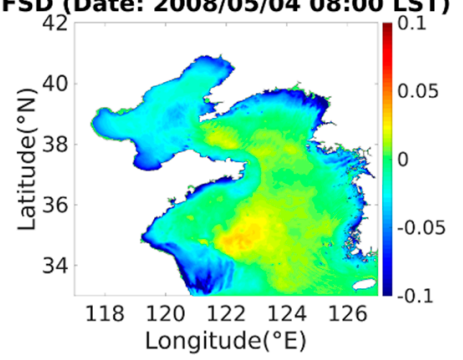


FSD (Date: 2008/05/04 09:00 LST)

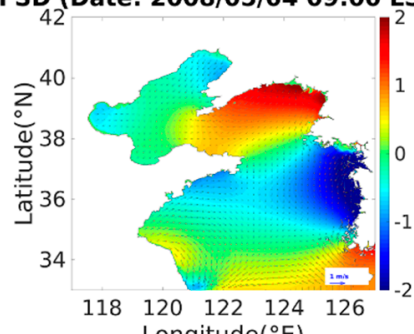

Longitude $\left({ }^{\circ} \mathrm{E}\right)$

FSD (Date: 2008/05/04 10:00 LST)

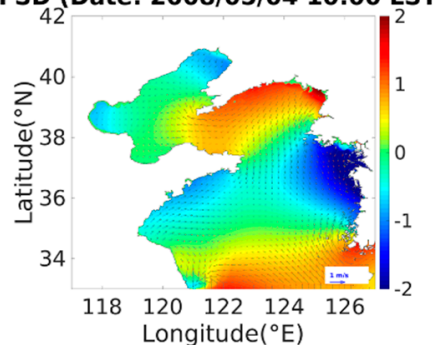

FSD (Date: 2008/05/04 11:00 LST)

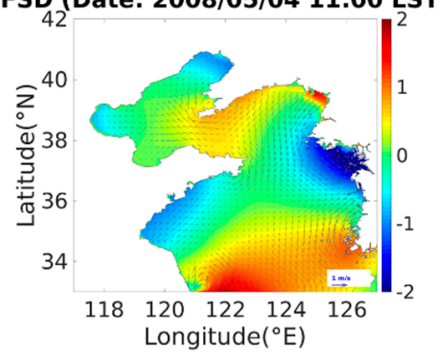

FSD (Date: 2008/05/04 12:00 LST)

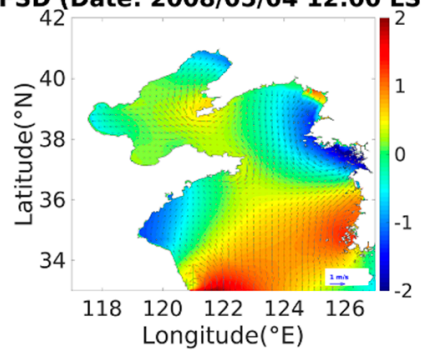

FSD (Date: 2008/05/04 13:00 LST)

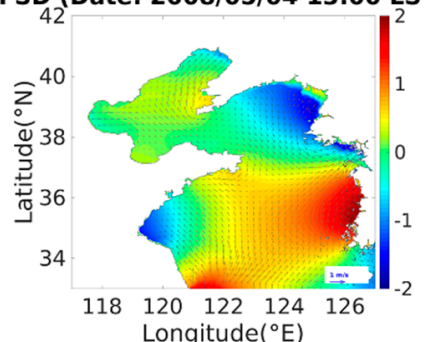

FSD (Date: 2008/05/04 14:00 LST)

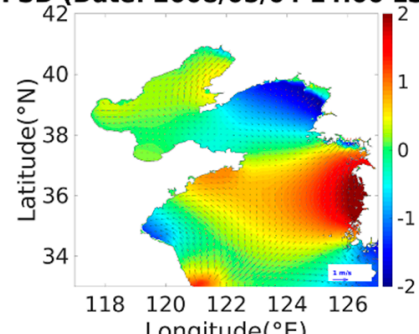

(a) Meteotsunami + Tide
FSD (Date: 2008/05/04 09:00 LST)

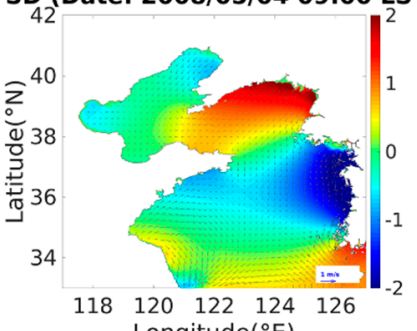

Longitude $\left({ }^{\circ} \mathrm{E}\right)$

FSD (Date: 2008/05/04 10:00 LST)

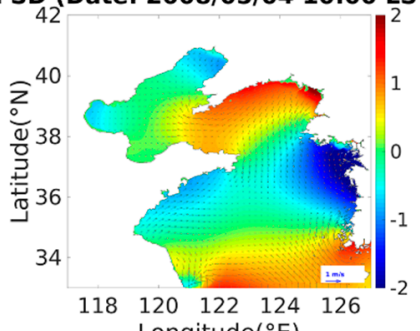

Longitude $\left({ }^{\circ} \mathrm{E}\right)$

FSD (Date: 2008/05/04 11:00 LST)

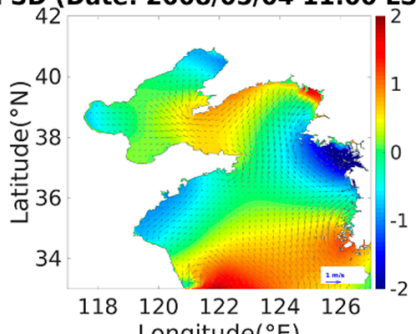

gitude $\left({ }^{\circ} \mathrm{E}\right)$

FSD (Date: 2008/05/04 12:00 LST)

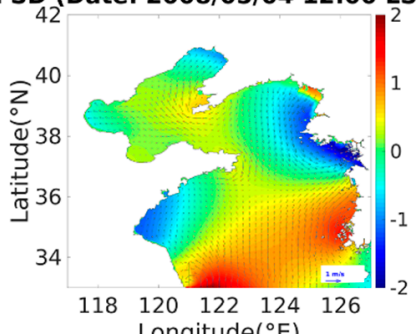

gitude $\left({ }^{\circ} \mathrm{E}\right)$

FSD (Date: 2008/05/04 13:00 LST)

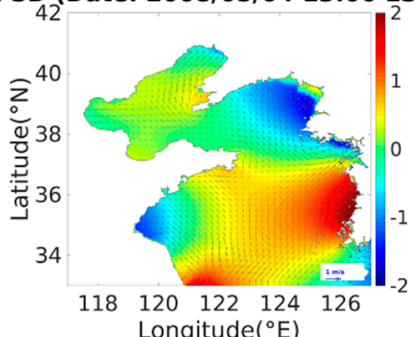

gitude $\left({ }^{\circ} \mathrm{E}\right)$

FSD (Date: 2008/05/04 14:00 LST)

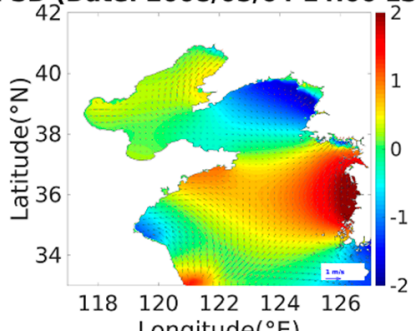

(b) Tide only
FSD (Date: 2008/05/04 09:00 LST)

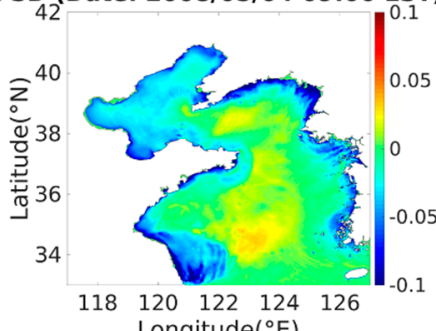

ongitude $\left({ }^{\circ} \mathrm{E}\right)$

FSD (Date: 2008/05/04 10:00 LST)

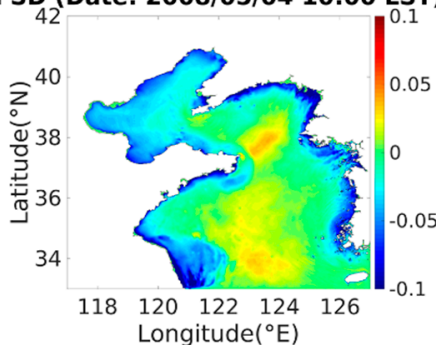

FSD (Date: 2008/05/04 11:00 LST)

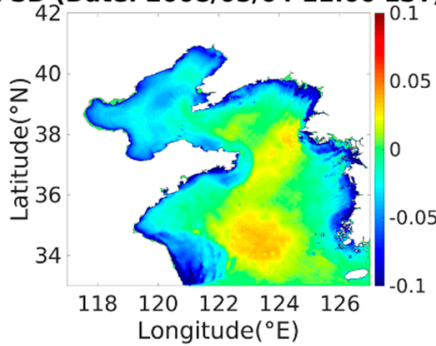

FSD (Date: 2008/05/04 12:00 LST)

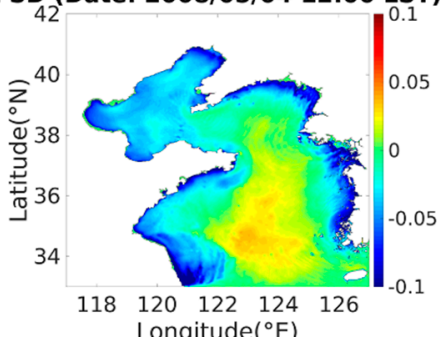

FSD (Date: 2008/05/04 13:00 LST)

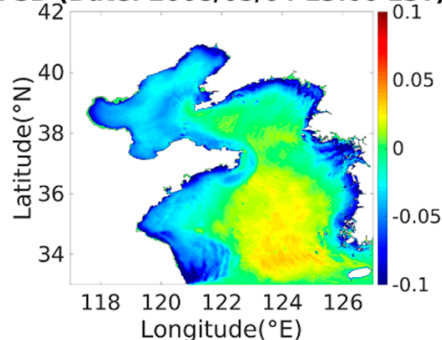

FSD (Date: 2008/05/04 14:00 LST)

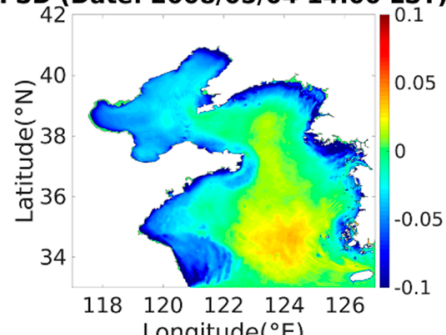

(c) Meteotsunami only

Figure 10. Comparison of the free surface displacement (FSD) change with tide modeling in the Yellow Sea during the meteotsunami that occurred in May 2008. (a) FSD change of the meteotsunami with tide modeling; (b) FSD change of tides; (c) FSD change of the meteotsunami only. 
The effects of tidal currents were further increased as the meteotsunami propagated over the Yellow Sea during the event. Figure 10a shows a somewhat different distribution of amplification that was slightly higher than that of tide only modeling shown in Figure 10b. After a brief pressure jump occurred in the middle of the Yellow Sea, the meteotsunami and tidal currents near the northeastern sea of the Shandong Peninsula developed toward the southeastern coast of the Korean Peninsula, and then the meteotsunami was slightly amplified due to the positive effects of tidal currents. Meanwhile, the meteotsunami generating on the southwestern sea propagated toward the western coast of the Korean Peninsula and experienced partially positive effects of tidal currents during propagation over the Yellow Sea. Consequently, Figure 10c shows relatively high wave heights compared with those without tide modeling in Figure 9.

\subsection{Discussion}

In this study, we employed a phase resolving wave model based on nonlinear shallow water equations to simulate meteotsunamis and tidal currents simultaneously. In general, a phase resolving wave model solves the governing equations of fluid particles and calculates water surface elevation and fluxes at each time step, approximately several seconds. This computational environment is quite different from that of phase averaged wave models based on wave energy equations, such as SWAN, WAM, WAVEWATCHIII, etc. Namely, a phase resolving wave model can consider nonlinear interaction of different wave motions at each time step without additional numerical techniques if the governing equations include nonlinear effects properly while phase averaged wave models consider nonlinear wave interaction by calculating additional source terms. Since we have employed a nonlinear shallow water equations model to consider the interaction between a meteotsunami and tidal currents, numerical results included effects of nonlinear interaction between a meteotsunami and tidal currents in themselves. We have simulated generation and amplification of meteotsunamis due to pressure changes under simultaneous tide modeling using boundary conditions of the numerical domain obtained from the global tide model, TPXO8. For tide modeling and generation of meteotsunamis due to pressure changes, we have modified the source code of COMCOT, in calculation of the boundary conditions and convection terms. We have discussed nonlinear interaction between meteotsunamis and tidal currents by comparing computed water elevation and fluxes with tide modeling to those without tide modeling in previous chapters and concluded tidal currents affected propagation of meteotsunamis over the Yellow Sea due to nonlinear interaction between them.

The Boussinesq models are based on superior governing equations and have been shown better performance in many coastal problems. However, for tsunami modeling over the ocean, the Boussinesq models sometimes show numerical instability as simulation time increases. In this study, we focused on nonlinear effects occurred during propagation of meteotsunamis over the Yellow Sea, such as meteotsunami-tide interaction, generation mechanism of meteotsunamis due to pressure changes, etc., and thus employed the nonlinear shallow equations model of COMCOT. However, the dispersive behavior of tsunamis can be a dominant factor of tsunami propagation nearshore and should be considered properly in numerical modeling of meteotsunamis. For more accurate modeling, the shallow equations model can be improved to consider physical dispersion and nonlinear effects simultaneously and remove model instability by diminishing additional numerical errors.

The numerical results need to be compared quantitatively with the observation. It has been identified in previous and present studies that meteotsunamis occurred in 2007 and 2008 were originated from abrupt atmospheric pressure disturbances generated during propagation of the atmosphere over the Yellow Sea. However, there have been no quantitative atmospheric observational data over the Yellow Sea during the events unfortunately. In previous studies, researchers have analyzed available observational data, such as weather radar images, weather charts, satellite images, inland automatic weather stations (AMSs) data, etc. as an alternative and qualitatively assumed propagation of atmospheric pressure disturbances. Among them, reference [7] has analyzed available observational data thoroughly and proposed a curved propagation line of atmospheric pressure disturbances over the 
Yellow Sea from detailed description of inland AMSs data while other studies assumed the propagation line as a simple straight line. Although detailed analysis of reference [7] has been limited to qualitative description of atmospheric pressure disturbances like other previous studies, it has been regarded as the most detailed description of meteotsunamis around the Korean Peninsula so far. Therefore, we have followed this work to verify the qualitative performance of the atmospheric model for modeling of meteotsunamis in Yellow Sea by comparing distribution shape of abrupt sea level pressure changes in Figures 7 and 9 to the propagation line of a meteotsunami represented in Figures 4 and 6.

Comparisons of temporal changes in simulated and observed sea levels are necessary to evaluate the model quantitatively. However, it is thought that quantitative comparison should be followed by qualitative verification of numerical modeling system. Before quantitative comparison of simulated sea levels with observed sea levels, we have focused on that atmospheric pressure disturbances over the Yellow Sea could be simulated using a conventional atmospheric model without any assumption to match numerical results to available observational data for a possible operational system monitoring meteotsunamis around the Korean Peninsula. The amplification of meteotsunami can be improved quantitatively by adding additional source terms represented Proudman resonance to the gonverning equations in a phase resolving wave model. Therefore, we have compared the distribution shape of abrupt sea level pressure changes in Figures 7 and 9 to the propagation line of a meteotsunami represented in Figures 4 and 6 to verify performance of the atmospheric model whether qualitatively, and investigated the abrupt sea level pressure changes could generate meteotsunami-like water surface elevation in a phase resolving wave model. It has been identified that both models performed well and meteotsunamis could be generated qualitatively in an operational ocean modeling system.

\section{Conclusions and Remarks}

In this study, a series of numerical experiments were conducted to identify the generation and amplification mechanisms of meteotsunamis occurring in the Yellow Sea, and numerical results with and without tide modeling were analyzed to examine the interaction between a meteotsunami and the tide. Both an atmospheric model and a phase-resolving wave model were employed to calculate the distribution of atmospheric pressure disturbances and corresponding wave conditions in the Yellow Sea. Although numerical modeling of the historical meteotsunami events well represented the overall transformation process of the meteotsunamis qualitatively, the numerical results quite quantitatively underestimated the wave heights of the meteotsunamis compared with the available observational data for both the 2007 and 2008 meteotsunamis. The discrepancies were caused by atmospheric pressure disturbances being calculated roughly in terms of time scale. Namely, the numerical results of the atmospheric model were calculated in a phase of approximately a few minutes, while the pressure jump observed during the historical events was generated and propagated in a phase of approximately a few seconds. As a result, the effect of atmospheric pressure disturbances was excessively smoothened and the wave heights of the meteotsunamis were underestimated. Furthermore, since the 2008 event was a small-scale meteotsunami, the grid system may have not been sufficient enough to consider nonlinear effects and variable topographies. The wind effects were also not considered in the numerical modeling, which could be the main sources of high run-up heights, and the discrepancy may have been caused by the lack of those sources. Numerical modeling with these sources may improve the numerical results quantitatively in the future.

For engineering purposes, this study focused on atmospheric pressure disturbances over the Yellow Sea that could be simulated using a conventional atmospheric model without any assumption to match numerical results to available observational data for a possible operational system monitoring meteotsunamis around the Korean Peninsula. Therefore, we have compared the distribution shape of abrupt sea level pressure changes to the propagation line of a meteotsunami to verify the performance of the atmospheric model qualitatively. Then, we investigated whether the abrupt sea level pressure changes could generate meteotsunami-like water surface elevation as well as nonlinear interaction between meteotsunamis and tidal currents in a phase resolving wave model. We have identified that 
both models performed well and meteotsunamis could be generated qualitatively in an operational ocean modeling system.

Author Contributions: This study was conceived and designed by K.-Y.H. and T.H.; the observational data was analyzed by J.-S.B., J.-S.Y., and T.H.; numerical modeling was conducted and numerical results were analyzed by K.-Y.H. and T.H.; the paper was written by T.H.; all authors contributed to revising of the manuscript.

Funding: This work was funded by the Korea Meteorological Administration Research and Development Program under Grant KMI2018-02410. This research was supported by Basic Science Research Program through the National Research Foundation of Korea (NRF) funded by the Ministry of Education (NRF-2017R1C1B1010921). This research was part of the project titled "Improvements of ocean prediction accuracy using numerical modeling and artificial intelligence technology," funded by the Ministry of Oceans and Fisheries, Korea.

Acknowledgments: We thank the Korea Meteorological Administration (KMA), the Korean Institute of Ocean Science and Technology (KIOST), and the National Centers for Environmental Prediction-National Center for Atmospheric Research for the dataset.

Conflicts of Interest: The authors declare no conflict of interests.

\section{References}

1. Defant, A. Physical Oceanography; Pergamon Press: Oxford, UK, 1961; Volume 2.

2. Rabinovich, A.B.; Monserrat, S. Meteorological tsunamis near the Balearic and Kuril Islands: Descriptive and statistical analysis. Nat. Hazards 1996, 13, 55-90. [CrossRef]

3. Monserrat, S.; Vilibić, I.; Rabinovich, A.B. Meteotsunamis: Atmospherically induced destructive ocean waves in the tsunami frequency band. Nat. Hazards Earth Syst. Sci. 2006, 6, 1035-1051. [CrossRef]

4. Lamb, H. Hydrodynamics; Dover publications: Cambridge, UK, 1932.

5. Proudman, J. The effects on the sea of changes in atmospheric pressure. Mon. Not. R. Astron. Soc. Geophys. Suppl. 1929, 2, 197-209. [CrossRef]

6. Vilibić, I.; Monserrat, S.; Rabinovich, A.B.; Mihanović, H. Numerical modelling of the destructive meteotsunami of 15 June 2006 on the coast of the Balearic Islands. Pure Appl. Geophys. 2008, 165, 2169-2195. [CrossRef]

7. Bae, J.S. Study of Meteorological Tsunamis Generated in the Yellow Sea. Ph.D. Thesis, Hanyang University, Seoul, Korea, 2012.

8. Choi, B.-J.; Park, Y.; Kwon, K. Generation and growth of long ocean waves along the west coast of Korea in March 2007. Ocean Polar Res. 2008, 30, 453-466. (In Korean) [CrossRef]

9. Choi, J.-Y.; Lee, D.-Y. Analysis of small-scale atmospheric pressure jumps related to the generation of abnormal extreme waves at Boryeong. Ocean Polar Res. 2009, 31, 379-388. (In Korean)

10. Cho, K.-H.; Choi, J.-Y.; Park, K.-S.; Hyun, S.-K.; Oh, Y.; Park, J.-Y. A synoptic study on tsunami-like sea level oscillations along the west coast of Korea using an unstructured-grid ocean model. J. Coast. Res. 2013, 65, 678-683. [CrossRef]

11. Oh, S.C.; Shin, C.H.; Yoon, S.B. Simulation of inundation along the west coast of Korea from the meteotsunami of 2007. J. Coast. Res. 2016, 75, 1202-1206. [CrossRef]

12. Ha, T.; Choi, J.-Y.; Yoo, J.; Chun, I.; Shim, J. Transformation of small-scale meteorological tsunami due to terrain complexity on western coast of Korea. J. Coast. Res. 2014, 70, 284-289. [CrossRef]

13. Ha, T.; Yoon, J.-S.; Heo, K.-Y. Numerical simulations of a meteotsunami using both atmospheric and phase-resolving wave models in the Yellow Sea. J. Coast. Res. 2018, 85, 11-15. [CrossRef]

14. Ha, T.; Park, K.-S.; Cho, J.-S.; Cho, Y.-S. Tsunami-tide interaction in the Southern Sea of the Korean Peninsula. In Proceedings of the 25th Annual International Ocean and Polar Engineering Conference (ISOPE-2015), Kona, HI, USA, 21-26 June 2015; pp. 759-764.

15. Ha, T.; Cho, Y.-S. Tsunami propagation over varying water depths. Ocean Eng. 2015, 101, 67-77. [CrossRef]

16. Kowalik, Z.; Proshutinsky, A. Tsunami-tide interactions: A Cook Inlet Case Study. Cont. Shelf Res. 2010, 30, 633-642. [CrossRef]

17. Kowalik, Z.; Proshutinsky, T.; Proshutinsky, A. Tide-tsunami interactions. Sci. Tsunami Hazards 2006, 24, $242-256$.

18. Tolkova, E. Tide-tsunami interaction in Columbia River, as implied by historical data and numerical simulations. Pure Appl. Geophys. 2012, 170, 1115-1126. [CrossRef] 
19. Skamarock, W.C.; Klemp, J.B.; Dudhia, J.; Gill, D.O.; Barker, D.M.; Duda, M.G.; Huang, X.-Y.; Wang, W.; Powers, J.G. A Description of the Advanced Research WRF Version 3; NCAR: Boulder, CO, USA, 2008.

20. Barker, D.; Huang, X.; Liu, Z.; Auligné, T.; Zhang, X.; Rugg, S.; Ajjaji, R.; Bourgeois, A.; Bray, J.; Chen, Y.; et al. The Weather Research and Forecasting Model's Community Variational/Ensemble Data Assimilation System: WRFDA. Bull. Am. Meteorol. Soc. 2012, 93, 831-843. [CrossRef]

21. Heo, K.-Y.; Ha, T.; Choi, J.-Y.; Park, K.-S.; Kwon, J.-I.; Jun, K. Evaluation of wind and wave simulations using different global reanalyses. J. Coast. Res. 2017, 79, 99-103. [CrossRef]

22. Lim, H.; Hong, S.-Y. Effects of bulk ice microphysics on the simulated monsoonal precipitation over east Asia. J. Geophys. Res. 2005, 110, 166-181. [CrossRef]

23. Iacono, M.; Delamere, J.; Mlawer, E.; Shephard, M.; Clough, S.; Collins, W. Radiative forcing by long-lived greenhouse gases: Calculations with the AER radiative transfer models. J. Geophys. Res. 2008, 113. [CrossRef]

24. Hong, S.-Y.; Noh, Y.; Dudhia, J. A new vertical diffusion package with an explicit treatment of entrainment processes. Mon. Weather Rev. 2006, 134, 2318-2341. [CrossRef]

25. Kain, J.S. The Kain-Fritsch Convective Parameterization: An Update. J. Appl. Meteorol. 2004, 43, $170-181$. [CrossRef]

26. Wang, X.; Liu, P.L.F. An explicit finite difference model for simulating weakly nonlinear and weakly dispersive waves over slowly varying water depth. Coast. Eng. 2011, 58, 173-183. [CrossRef]

27. Egbert, G.D.; Bennett, A.F.; Foreman, M.G.G. Topex/Poseidon tides estimated using a global inverse model. J. Geophys. Res. 1994, 99, 24821-24852. [CrossRef]

28. Egbert, G.D.; Erofeeva, S.Y. Efficient inverse modeling of barotropic ocean tides. J. Atmos. Ocean. Technol. 2002, 19, 183-204. [CrossRef]

29. Egbert, G.D.; Erofeeva, S.Y.; Ray, R.D. Assimilation of altimetry data for nonlinear shallow-water tides: Quarter-diurnal tides of the Northwest European Shelf. Cont. Shelf Res. 2010, 30, 668-679. [CrossRef]

30. Stammer, D.; Ray, R.D.; Andersen, O.B.; Arbic, B.K.; Bosch, W.; Carrère, L.; Cheng, Y.; Chinn, D.S.; Dushaw, B.D.; Egbert, G.D.; et al. Accuracy assessment of global barotropic ocean tide models. Rev. Geophys. 2014, 52, 243-282. [CrossRef]

31. Yoon, J.-S.; Lee, J.; Ha, T. Development of a numerical algorithm considering tide-tsunami interaction. J. Coast. Res. 2019, 91, 11-15.

32. Seo, S.-N. Digital 30sec gridded bathymetric data of Korea marginal seas-KorBathy30s. J. Korea Soc. Coast. Ocean Eng. 2008, 20, 110-120. (In Korean)

33. Yoo, J.; Lee, D.-Y.; Ha, T.; Cho, Y.-S.; Woo, S.-B. Characteristics of abnormal large waves measured from coastal videos. Nat. Hazards Earth Syst. Sci. 2010, 10, 947-956. [CrossRef] 